\title{
Mechanical behaviour of heavily compacted bentonite under high suction changes
}

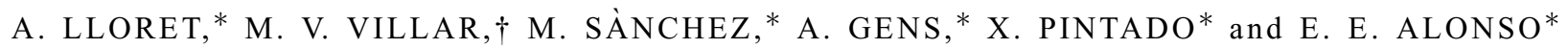

The paper reports the results of an experimental study carried out on a bentonite compacted to a dry density of up to $1 \cdot 7 \mathrm{Mg} / \mathrm{m}^{3}$, a high value for this type of soil. The soil fabric has been studied using a variety of techniques, revealing a clear bimodal pore distribution that corresponds to two distinct structural levels: a microstructural one and a macrostructural one. The main testing programme has been performed using oedometers especially designed to apply a very large range of suctions. By applying the axis-translation technique (using nitrogen as the gas fluid), it has been possible to reach suctions up to $15 \mathrm{MPa}$. The higher suction range has been achieved by applying a controlled atmosphere where the relative humidity has been fixed by a solution of sulphuric acid or salts. In this way suctions up to 550 MPa could be reached. The maximum vertical stress that could be applied in the apparatus was $10 \mathrm{MPa}$. Two types of test have been carried out: (a) tests in which a combination of loading paths at constant suction and drying/wetting paths at constant load were applied; (b) swelling tests under constant-volume conditions in order to determine the swelling pressure and the stress path followed during wetting. The results of the experimental programme are examined, taking into account the role of the soil fabric in controlling observed mechanical behaviour. In addition, the results of the laboratory tests are reproduced and interpreted using a generalised plasticity model that considers explicitly the interaction between macrostructure and microstructure. In this way, it is possible to achieve a more complete understanding of the mechanisms that underlie observed behaviour, and in particular the interplay between the two structural levels.

KEYWORDS: constitutive relations; expansive soils; fabric/ structure of soils; laboratory tests; radioactive waste disposal; suction
Cet exposé rapporte les résultats d'une étude expérimentale effectuée sur une bentonite compactée jusqu'à une densité sèche de $1,7 \mathrm{Mg} / \mathrm{m} 3$, valeur élevée pour ce type de sol. La structure du sol a été étudiée en utilisant une variété de techniques révélant une distribution de pores nettement bimodale qui correspond à deux niveaux structuraux distincts: un niveau microstructural et un niveau macrostructural. Le programme d'essais principal a été réalisé en utilisant des odomètres spécialement conçus pour appliquer une très vaste gamme de succions. En appliquant une technique de translation d'axe (utilisant de l'azote comme gaz fluide), il a été possible d'atteindre des succions allant jusqu'à 15 Mpa. La plage de succion la plus élevée a été obtenue en appliquant une atmosphère contrôlée où l'humidité relative avait été fixée par une solution d'acide sulfurique ou de sels. De cette manière, on a pu atteindre des succions allant jusqu'à 550 Mpa. La contrainte verticale maximum qui a pu être appliquée dans l'appareil était de $10 \mathrm{MPa}$. Deux types d'essais ont été effectués :

- Des essais dans lesquels une combinaison de chemins dechargement à succion constante et de chemins séchage/ humectage à charge constante ont été appliqués

- Des essais de gonflement en conditions volumiques constantes afin de déterminer la pression de gonflement et le chemin de contrainte suivi pendant l'humectage.

Nous examinons les résultats de ce programme expérimental en étudiant en quoi la structure du sol affecte le comportement mécanique observé. De plus, nous reproduisons les résultats des tests en laboratoire et nous les interprétons en utilisant un modèle de plasticité généralisé qui tient compte de manière explicite de l'interaction entre macrostructure et microstructure. De la sorte, nous avons pu approfondir notre compréhension des mécanismes qui régissent le comportement observé, notamment l'interaction entre les deux niveaux structuraux.

\section{INTRODUCTION}

Compacted bentonite is often used as the basic material for constructing isolating barriers in geoenvironmental applications or as basal and cap liners for landfills/retention basins (Koch, 2002). High-density compacted bentonite in the form of blocks has also been proposed as sealing material in high-level radioactive waste repositories, as it provides very low permeability, high exchange capacity, sufficient thermal conductivity, and adequate mechanical resistance. There is

\footnotetext{
Manuscript received 2 May 2002; revised manuscript accepted 2 October 2002.

Discussion on this paper closes 1 August 2003, for further details see p. ii.

* Department of Geotechnical Engineering and Geosciences, Universitat Politècnica de Catalunya (UPC), Barcelona, Spain.

$\uparrow$ Department of Environmental Impact of Energy, Centro de Investigaciones Energéticas, Mediambientales y Tecnológicas (CIEMAT), Madrid, Spain.
}

therefore a need to advance understanding of the mechanical behaviour of this type of material.

Although bentonite (montmorillonite) pastes have been actively studied in the past (e.g. Warkentin et al., 1957; Callaghan \& Ottewill, 1974; Ormerod \& Newman, 1983; Kraehenbuehl et al., 1987), knowledge concerning the mechanical behaviour of compacted bentonite is still scarce. The microstructure of compacted expansive clays has been studied by Pusch (1982), who observed a double structure made up of clay aggregates and large macrostructural pores. The pore space inside the aggregates was constituted of voids of a much smaller size. The same double structure has been identified in several compacted clays intended for engineered barriers in waste disposal (e.g. Atabek et al. (1991) in FoCa clay, Romero et al. (1999) in Boom clay, Pusch \& Moreno (2001) in MX80, and Cui et al. (2002a) in a mixture of $70 \%$ Kunigel clay and 30\% Hostun sand). As indicated in Gens \& Alonso (1992), Alonso (1998), Yong (1999) and Cui et al. (2002b), the behaviour of this material is potentially very complex, as it results from the interaction between the 
volume change of aggregates made up of a highly expansive clay mineral (microstructural level) and the rearrangement of the granular-like skeleton formed by the aggregates (macrostructural level). The microstructural level is the seat of the physico-chemical phenomena occurring at clay particle level, and in the conceptual model introduced in Gens \& Alonso (1992) it is assumed that the microstructural deformation behaviour is fully reversible and not affected by the state of the macrostructure. Also, the microstructural level is likely to be saturated, and therefore Terzaghi's effective stress principle holds. In contrast, the macrostructure will desaturate when subjected to suction, and its behaviour may be described by conventional frameworks for unsaturated soils. Although the behaviour of the microstructure is expected to be independent of the macrostructure, there is an important influence of the microstructure on the macrostructural level, where it can induce significant plastic strains. The magnitude of the interaction depends on the current stress state and on the density of the macrostructure.

The experimental study of this type of material presents very significant challenges. One of the most important is the need to cover large suction ranges, reaching on occasion values as high as $500 \mathrm{MPa}$. A good system of control of high suctions is essential, as only the performance of suction-controlled tests will allow a sound interpretation of the results obtained. Moreover, the low permeability of the bentonite implies very long testing times that place severe constraints on the extent of the testing programmes. Finally, there is also a need to apply or sustain high levels of stresses; swelling pressures can be very high if the bentonite is heavily compacted. A range of new experimental

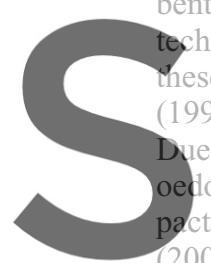
niques has been recentl materials. Bernier et 1999), Villar (1999), Cuis leck \& Börgesson (2001) edometers based on various cted clays, whereas Wiebe sand/bentonite mixtures using a triaxial apparatus that allows

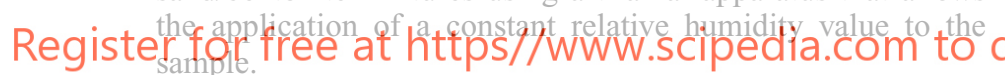

This paper reports the results of an experimental study carried out on a bentonite heavily compacted to a dry density of up to $1.7 \mathrm{Mg} / \mathrm{m}^{3}$. Given its importance, the soil fabric has been studied using a variety of techniques. The testing programme has been carried out using oedometers especially designed to apply a very large range of suctions, up to $550 \mathrm{MPa}$, and vertical loads up to $10 \mathrm{MPa}$. In the paper the results of constant load tests, constant suction tests and swelling pressure tests are examined and discussed, taking into account the role of the soil fabric.

The results of the experimental programme are interpreted and reproduced by means of a generalised plasticity model that considers explicitly the interaction between macrostructure and microstructure. In this way, it is possible to view the results of the tests performed in a unified manner within a consistent theoretical framework.

\section{PROPERTIES AND FABRIC OF THE MATERIAL}

The tests have been performed on a bentonite from the Cortijo de Archidona deposit in Almería, south-eastern Spain. The conditioning of the bentonite in the quarry, and later in the factory, was strictly mechanical, consisting of homogenisation, removal of rock fragments, drying at $60^{\circ} \mathrm{C}$ and crumbling of clods. Finally, the clay was sieved using a $5 \mathrm{~mm}$ square mesh to obtain the product to be used in the laboratory.

The bentonite has a montmorillonite content higher than
$90 \%$. It also contains variable quantities of quartz and other minerals such as plagioclase, cristobalite, potassium feldspar, calcite and trydimite. The cation exchange capacity is of $111 \pm 9 \mathrm{meq} / 100 \mathrm{~g}$, and the exchangeable cations are $\mathrm{Ca}$ (38\%), Mg (28\%), $\mathrm{Na}(23 \%)$ and $\mathrm{K}(2 \%)$. The liquid limit of the bentonite is $102 \pm 4 \%$, the plastic limit is $53 \pm 3 \%$ and the hygroscopic water content of the clay at laboratory conditions (relative humidity $50 \pm 10 \%$, temperature $21 \pm 3^{\circ} \mathrm{C}$ ) is about $13 \cdot 7 \pm 1 \cdot 3 \%$. The value obtained for the external specific surface using the BET technique is $32 \pm 3 \mathrm{~m}^{2} / \mathrm{g}$, and the total specific surface obtained using the Keeling hygroscopicity method is about $725 \mathrm{~m}^{2} / \mathrm{g}$. The relatively low values of the Atterberg limits can be explained by taking into account the significant quantity of silt-sized aggregates that are 'pseudomorphs' of the volcanic minerals transformed into smectite (Villar, 2002).

As mentioned above, the fabric of the compacted soil plays an important role in the observed swelling behaviour of these materials. Mercury intrusion porosimetry (MIP) tests have been performed to examine the pore size distribution of the statically compacted material used in the experimental programme. Fig. 1 shows the measured incremental pore volume for two samples compacted to very different values of dry density $\left(\rho_{\mathrm{d}}\right), 1.5 \mathrm{Mg} / \mathrm{m}^{3}$ and $1.8 \mathrm{Mg} / \mathrm{m}^{3}$. It can be observed that the pore size distribution is clearly bimodal, which is very characteristic of this type of material (Alonso et al., 1987). The dominant values are $10 \mathrm{~nm}$, which would correspond to the pores inside clay aggregates, and a larger pore size that depends on the compaction dry density and ranges from $10 \mu \mathrm{m}$ (for $\rho_{\mathrm{d}}=1.8 \mathrm{Mg} / \mathrm{m}^{3}$ ) to $40 \mu \mathrm{m}$ (for $-1.5 \mathrm{Mg} / \mathrm{m}^{3}$ ). These larger voids would correspond to

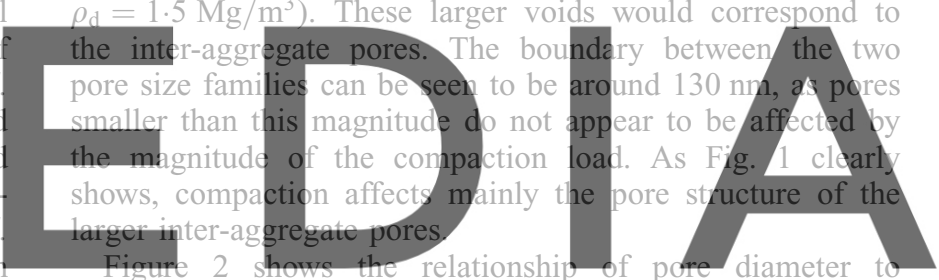
intruded pore volume for two samples compacted at dry

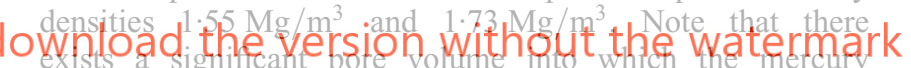
could not penetrate given by the difference between the void ratio of the soil and the void ratio intruded by the mercury. The magnitude of this volume $(e=0 \cdot 32)$ is practically the same for the two specimens. Indeed, the intra-aggregate pore volumes are very similar for the two samples, with void ratio values around $0 \cdot 46$. The remaining of the pore space

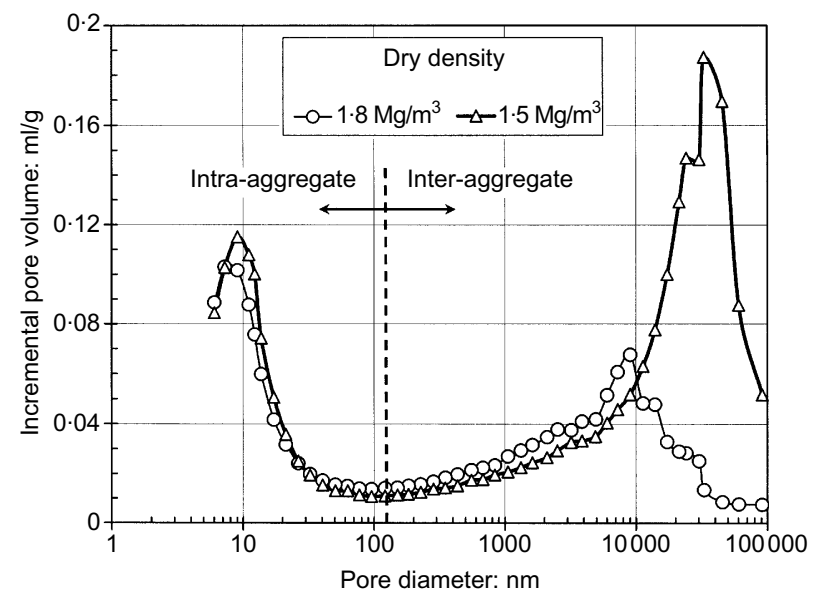

Fig. 1. Distribution of incremental pore volume for two compacted bentonite samples at different dry densities. Mercury intrusion porosimeter test 


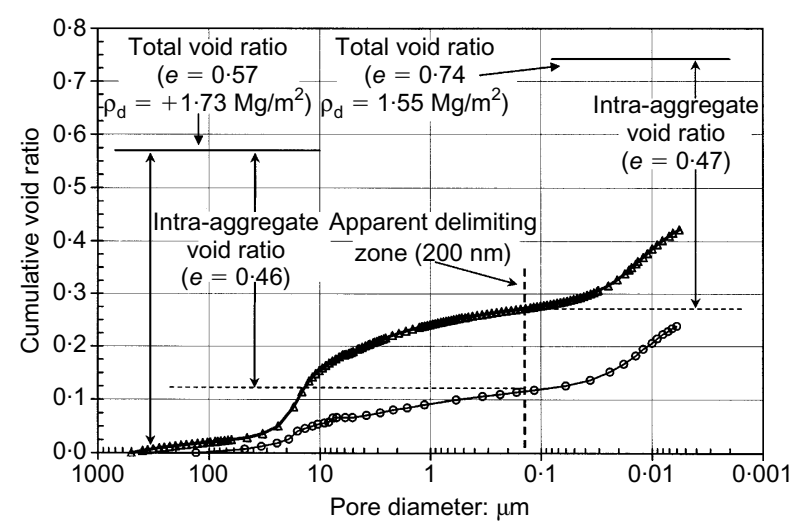

Fig. 2. Relationship between pore diameter and intruded pore volume for two samples compacted at different dry densities. Mercury intrusion porosimeter test

therefore corresponds to inter-aggregate pores, accounting for about $37 \%$ of the voids $(e=0.28)$ in the sample with a dry density of $1.55 \mathrm{Mg} / \mathrm{m}^{3}$ and about $20 \%(e=0.11)$ in the sample with a dry density of $1.72 \mathrm{Mg} / \mathrm{m}^{3}$. Fig. 3 shows a micrograph obtained using an environmental scanning electron microscope where the presence of aggregates, the size of the inter-aggregate voids and the bimodal distribution of pore sizes are readily apparent. Similar observations have been reported in Cui et al. (2002a)

Additional information on the soil fabric can be inferred from an examination of retention curves obtained under free sweling and constant-volume cond

observed that the water retained

about $15 \mathrm{MPa}$ is independent of

density). It seems plausible that

high suctions belongs to the intra-

total porosity plays no relevant

fact that the water content
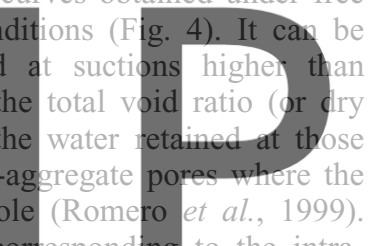

sponding to the intra-

aggregate pores appears to be somewhat higher than their

Register for free at https//WWW.Scipedia.com to

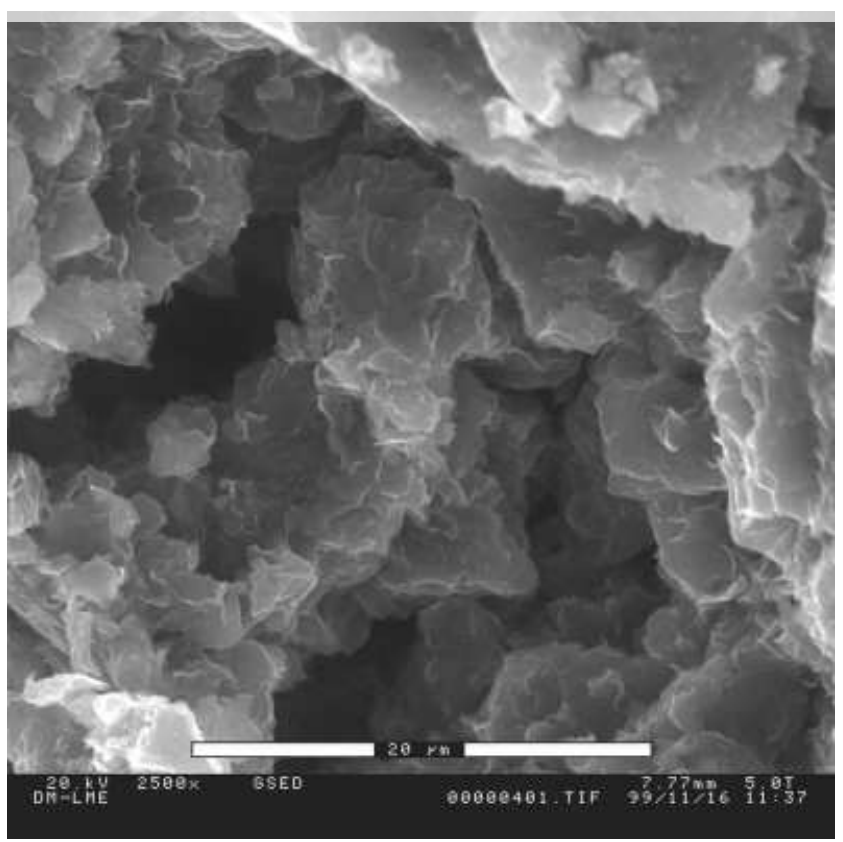

Fig. 3. Micrograph of a compacted bentonite sample (dry density $=1.72 \mathrm{Mg} / \mathrm{m}^{3}$ ) obtained using an environmental scanning electron microscope

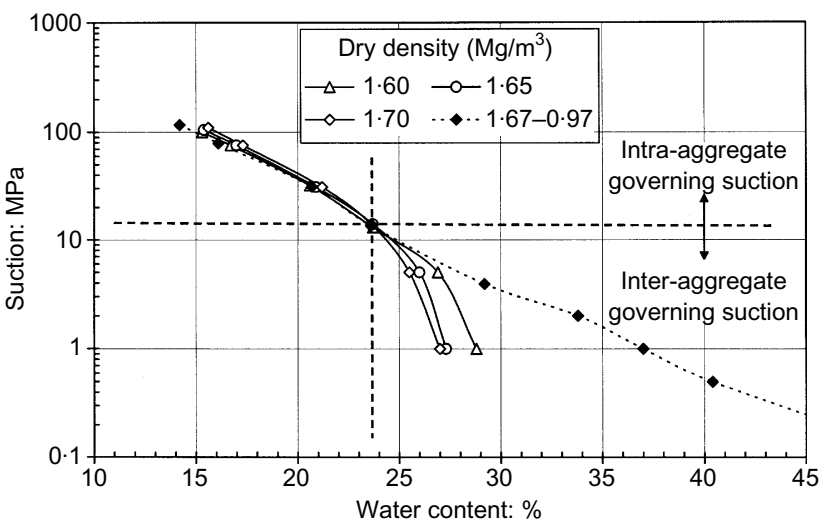

Fig. 4. Retention curves for compacted bentonite obtained under free swelling and constant-volume conditions

the fact that the density of the water tightly bound to the clay particles is higher than that of free water (Martin, 1962, Villar, 2002). It is also likely that part of the water is retained on the surface of the aggregates. Summarising, all the observational data concerning the fabric of compacted soils indicate a clear presence of two structural levels in the material: a microstructure inside the aggregates and a macrostructure consisting of the ensemble of aggregates and inter-aggregate pores. Microstructure features appear to be largely independent of compaction effort.

\section{The saturated permeability of the benton}
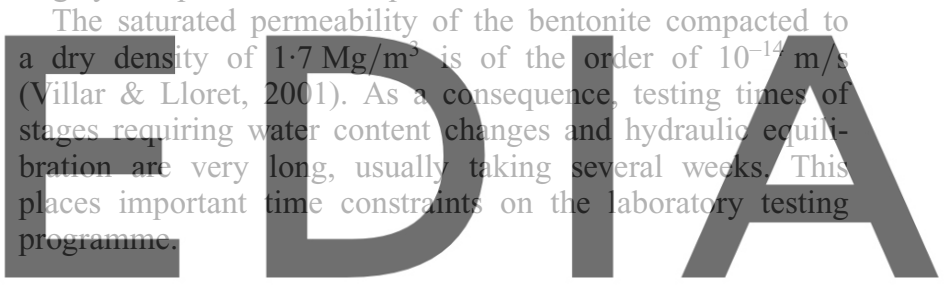

\section{download the varsion withowt the thatermark PROCEDURES}

Oedometer tests with suction control have been carried out at CIEMAT and UPC laboratories. The main limitation of oedometer testing is that it does not provide full information on the stress state of the material, as the horizontal confining stress is not usually measured. As a result, difficulties are sometimes encountered in the interpretation of the results and in the comparison with model predictions. In addition, in the case of unsaturated soils, there is also uncertainty regarding the degree of saturation of the soil, which is always unknown, although the retention curves obtained at constant volume may provide an approximate water content for every suction value. However, most significant trends and features of soil behaviour may be obtained using this type of test (Gens \& Alonso, 1992), the performance of which is far less complex than that of triaxial tests. Moreover, testing times are shorter in oedometer tests as compared with triaxial tests, a paramount consideration when testing materials with such a low coefficient of permeability. To reduce the duration of the tests further, the initial thickness of the specimens was selected to be $12 \mathrm{~mm}$ approximately, smaller than that of conventional oedometer samples. Friction effects, always a concern in oedometer tests, were thereby also reduced.

The main objectives of performing the series of tests reported here have been to identify the main patterns of compacted bentonite behaviour and to increase the experimental data available on the strain behaviour of very 
expansive compacted materials under conditions of high suction. Two types of test were carried out:

(a) tests in which a combination of loading paths at constant suction and wetting and drying paths at constant load were applied

(b) swelling tests under constant-volume conditions in order to determine the swelling pressure and the stress path followed during wetting.

The first type of test was carried out at the CIEMAT laboratory. Apart from the initial and final equilibration stages, the actions applied on the samples have been load increments at constant suction and changes of suction at constant load. Samples were compacted statically to a dry density of $1.70 \pm 0.02 \mathrm{Mg} / \mathrm{m}^{3}$ with the material at hygroscopic water content.

Because of the high suction values that have to be reached in the study of this type of material, the procedure for applying prescribed values of suction requires special consideration. For suction values less than $14 \mathrm{MPa}$, the axistranslation technique has been used in a cell of the type described in Escario \& Sáez (1973). The base of the cell has an embedded porous stone, below which there are two inlet and outlet holes, connected to a burette with water at atmospheric pressure. A cellulose membrane is placed over this stone, with the sample resting directly on it. This membrane allows water and ions to pass, but not gas. A peristaltic pump, installed between the burette and the cell inlets, facilitates the removal of the gas that could diffuse through the membrane. Nitrogen is used to apply the gas pressure in excess of the water pressure on top of the sample.

Higher suction values have value of the relative humidity of

with the sample (Esteban 1990

lative humidity are related

In turn, relative humidit

lutions of sulphuric
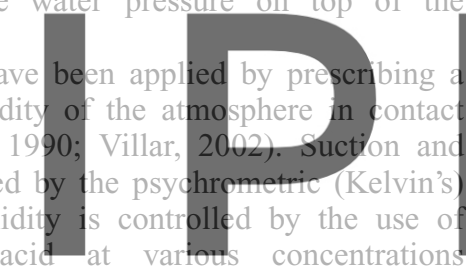

concentrations

(Esteban, 1990) or of saturated solutions of various salts

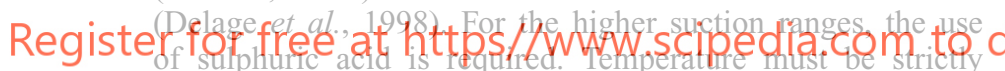
controlled, as the activity of the solution is very sensitive to thermal fluctuations. With this technique, it was possible to apply total suctions in the range between $3 \mathrm{MPa}$ and $500 \mathrm{MPa}$. Suctions less than $3 \mathrm{MPa}$ are not reliable because it was difficult to ensure the necessary level of temperature stability. The oedometer cell used in this case is depicted in
Fig. 5, where the solution reservoirs placed above the specimen can be seen.

The swelling tests under constant volume have been performed in the UPC laboratory. These tests aim to reproduce the conditions during hydration of an engineered barrier in underground waste repositories where the compacted bentonite is rigidly constrained by the waste canister and the host rock (Fig. 6). Samples were compacted at an initial dry density of $1.63 \pm 0.01 \mathrm{Mg} / \mathrm{m}^{3}$ at hygroscopic water content $(13.7 \pm 1.3 \%)$. This density is somewhat lower than in the specimens reported previously because there is some capacity for the barrier to expand slightly initially owing to the presence of gaps between the compacted blocks of bentonite. Four swelling pressure tests have been performed.

A schematic layout of the oedometer used in this type of test is presented in Fig. 7. To prevent the swelling of the soil in the constant-volume stages, the lever arm is fixed (Bjerrum et al., 1964); a load cell measures the development of the swelling pressure. To permit the application of high loads, the lever arm has a loading ratio of up to $1: 20$. Suction is again applied by means of an atmosphere with controlled relative humidity. In this oedometer cell the air is circulated, by means of a peristaltic pump, through the porous plates located at the two ends of the sample.

\section{TEST RESULTS}

Table 1 presents the initial conditions and the stress paths of five tests in which a combination of loading paths at constant suction and suction change paths at constant load

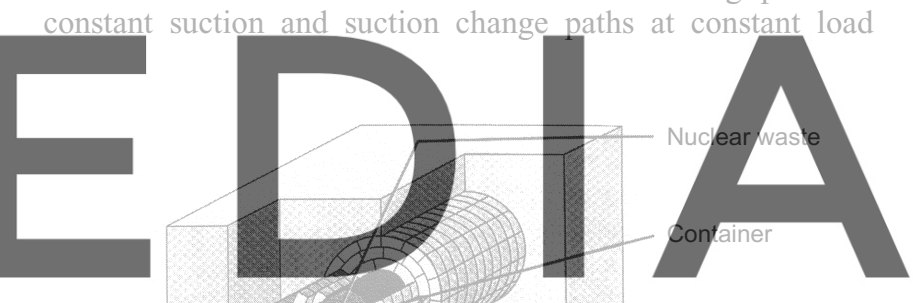

download the version without theombated

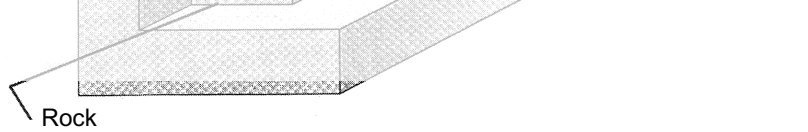

Fig. 6. Proposed engineered barrier made up of compacted bentonite clay for a radioactive waste repository

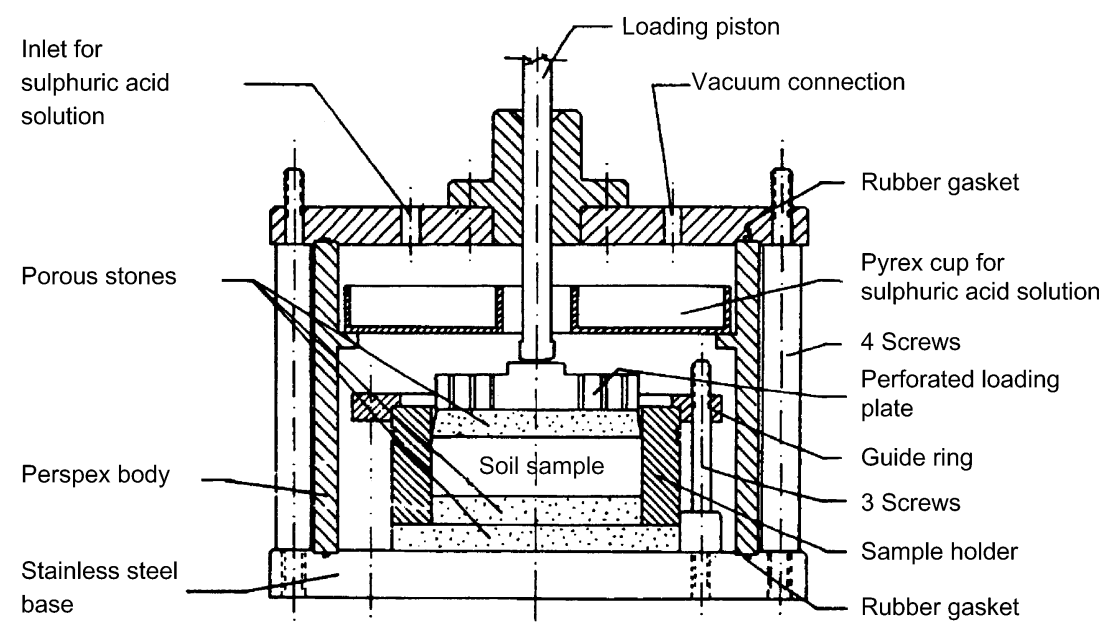

Fig. 5. Schematic layout of the high-suction oedometer used in the CIEMAT laboratory (Esteban, 1990) 


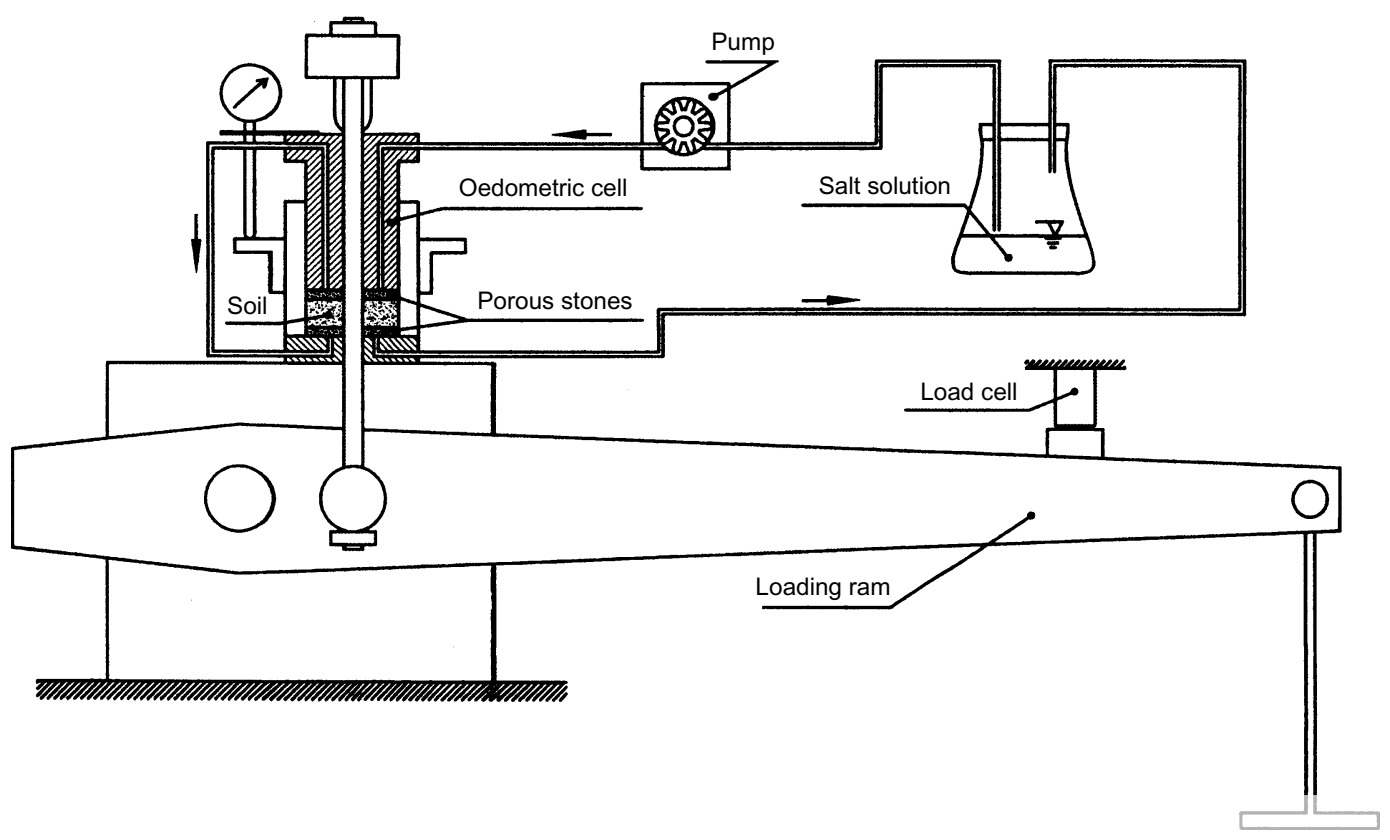

Fig. 7. Schematic layout of the high-suction oedometer used in the UPC laboratory

Table 1. Stress paths of the tests, in which a combination of loading paths at constant suction and suction change paths at constant load were applied. Tests performed at CIEMAT laboratory

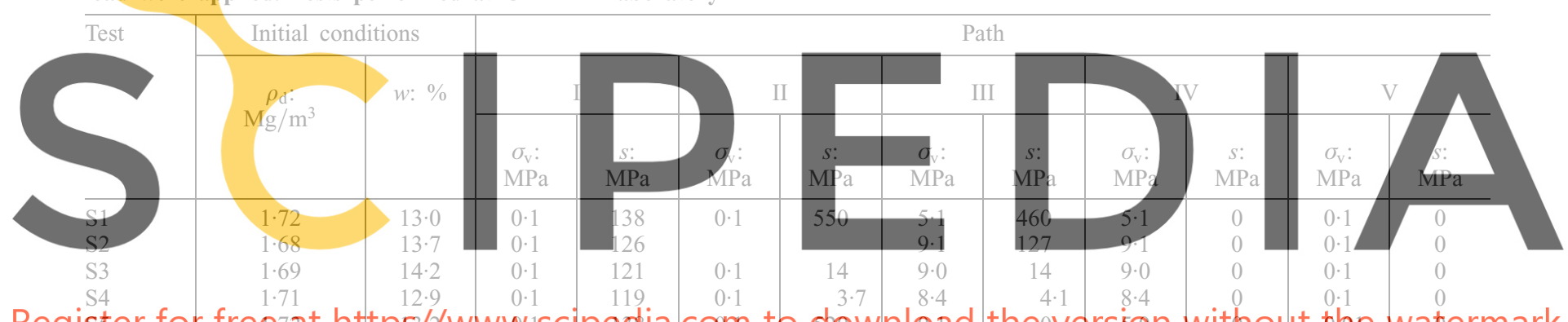

have been applied. The various load or suction changes were applied in stages, as shown in Fig. 8. In order to use a logarithmic scale a constant value of $0 \cdot 1 \mathrm{MPa}$ has been added to all suction values plotted in this figure. The same convention has been used in the rest of the paper. All tests

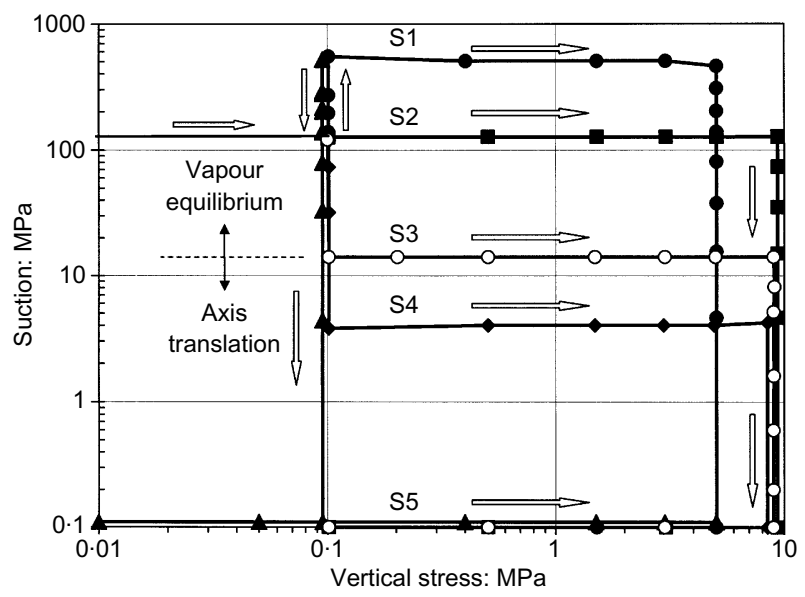

Fig. 8. Generalised stress paths followed by tests S1-S5 start at an applied vertical stress of $0 \cdot 1 \mathrm{MPa}$ and at the compaction suction of about $125 \mathrm{MPa}$. Afterwards a variation of suction is applied under constant load, except for one specimen in which suction was kept unchanged. Afterwards the load was increased also under constant suction, which was then followed by wetting to saturation (zero suction). Maximum vertical stresses under saturated conditions were either $5 \mathrm{MPa}$ or $9 \mathrm{MPa}$, depending on the test.

Figure 9 shows the variation of void ratio during the initial stage of suction modifications and subsequent loading. The starting points for the loading stages are very different because of the large dependence of volumetric strains on suction applied at low loads. On loading, the stiffness of the bentonite (that is, the slope of the void ratio against the vertical stress line plotted on a semi-logarithmic scale) reduces slightly as the suction applied during loading increases. However, the most noticeable effect of suction is the shifting of the point at which there is a change in the slope of these lines, indicated by a vertical arrow in Fig. 9. In the framework of elasto-plasticity this change is interpreted as the crossing of a yield surface, and the load at which it takes place can be considered as an apparent preconsolidation pressure. Fig. 10 shows the dependence of this preconsolidation pressure on suction. Large preconsolidation pressure reductions are apparent at low suction 


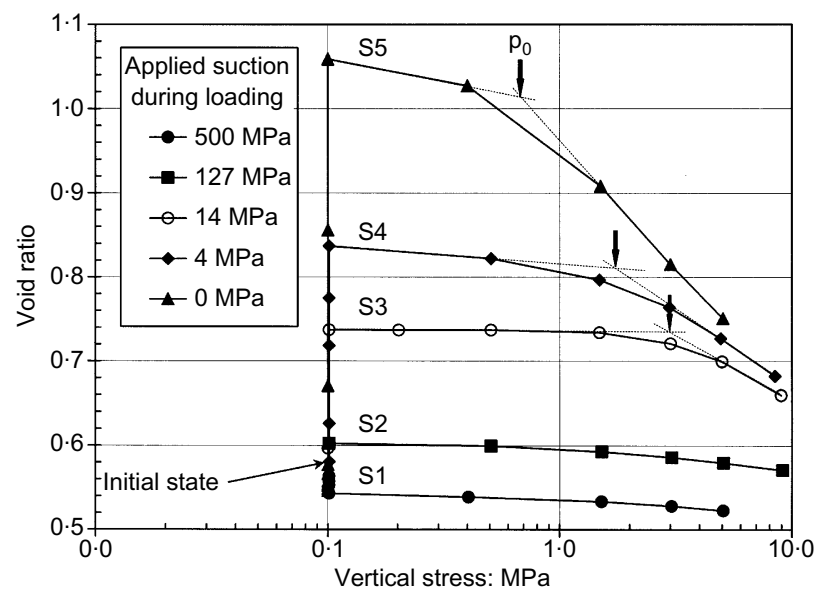

Fig. 9. Variation of void ratio during the initial stage of suction variation and subsequent loading. Tests S1-S5

values. According to the conceptual model of Gens \& Alonso (1992), the reduction of the yield point is due to the irreversible macrostructural strains induced by microstructural deformations that have occurred during the swelling to low suction values. Yielding was not reached in tests S1 and S2, and in the plot of Fig. 10 it is assumed that the preconsolidation stress corresponds approximately to the vertical stress value reached during static compaction, about $18 \mathrm{MPa}$.

The variations of void ratio during the stages at which the vertical stress is maintained const

are presented in Fig. 11.

observed in the specimens

O. $\mathrm{MPa}$, whereas in the samples
at $5.1 \mathrm{MPa}$ and, especially,

terms of the slope of the swellin ine (in a semi-

logarithmic plot) with the applied vertical stress during

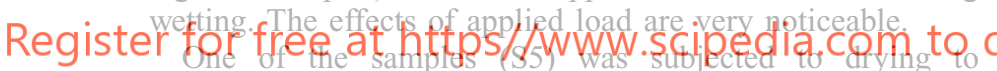

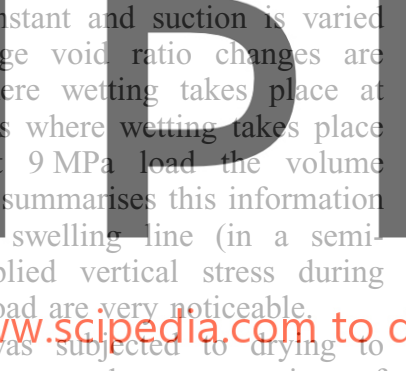

$500 \mathrm{MPa}$ suction before being wetted to a suction of
$0.1 \mathrm{MPa}$. The measured void ratio changes are plotted in

Fig. 13. It can be seen that the drying produces very small volumetric strains. However, when wetting is continued

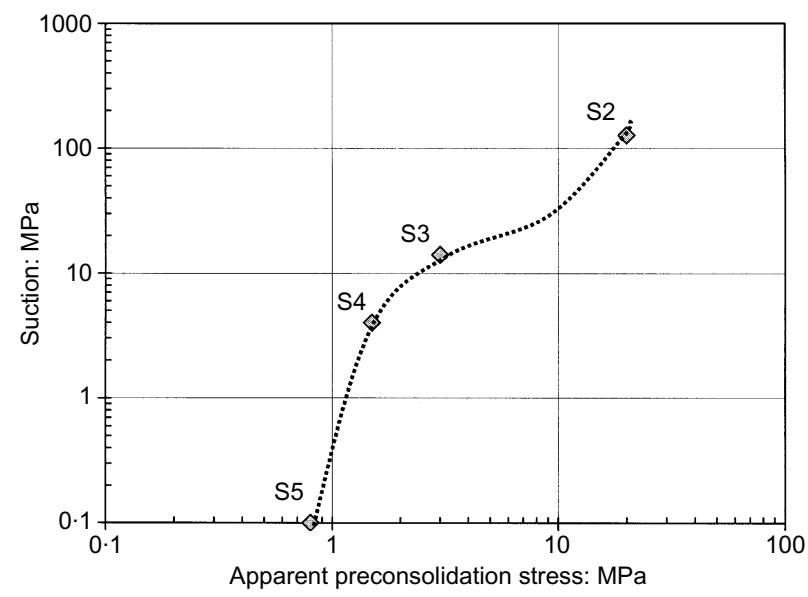

Fig. 10. Relationship between apparent preconsolidation stress and applied suction identified in loading stages of tests $\mathrm{S3}, \mathrm{S} 4$ and $S 5$. The preconsolidation stresses of samples $S 1$ and $S 2$ are assumed to be approximately equal to the static compaction stress

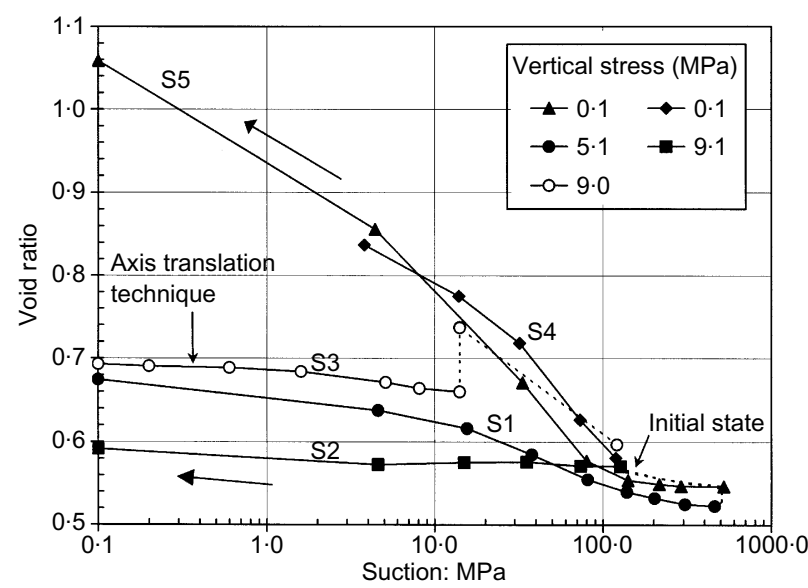

Fig. 11. Variation of void ratio during the stages at which vertical stress is maintained constant and suction varied. Tests S1-S5

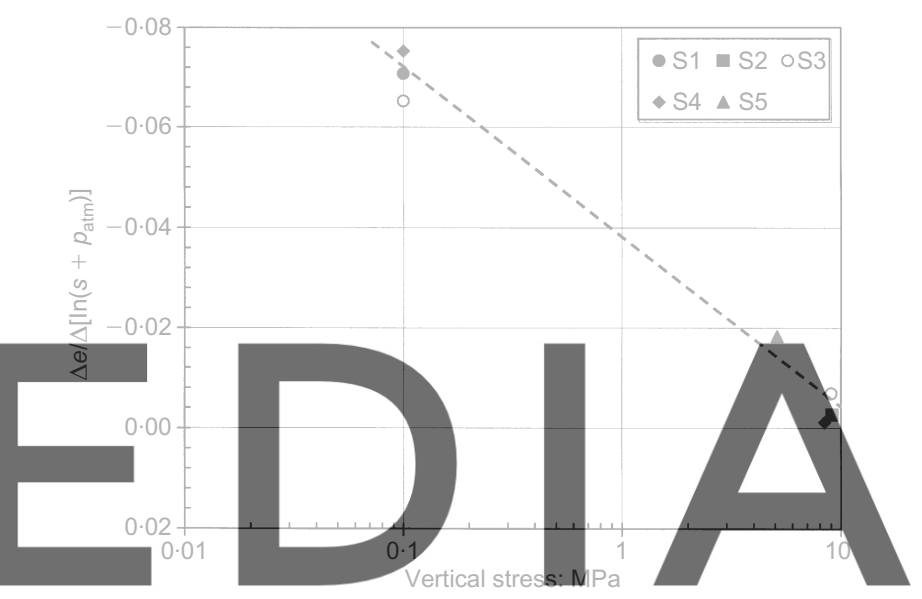

Fig. 12. Influence of applied vertical stress on slope of swelling

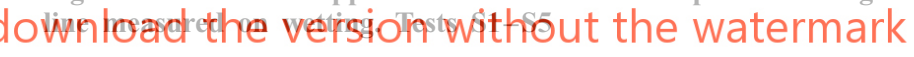

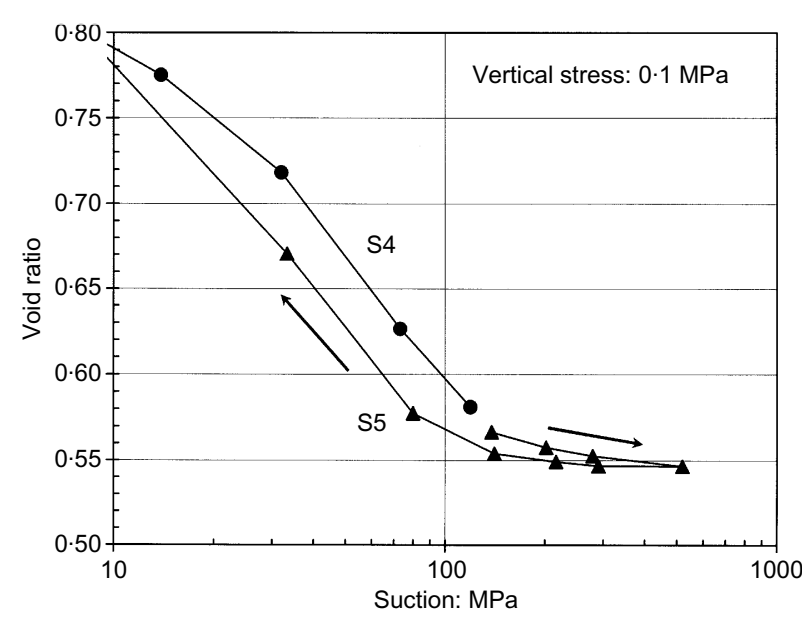

Fig. 13. Variation of void ratio with suction of test S5 during an initial drying/swelling cycle and subsequent wetting. The results of test $\mathrm{S} 4$ are included for comparison

towards smaller suction values a large increase of swelling strains is observed, signalling a significant change of behaviour. A comparison of the results of this test with those of test S4, which did not undergo this initial drying/wetting 
cycle (Fig. 13), suggests that such a suction cycle does not have any noticeable effects on subsequent behaviour.

An important feature of behaviour concerns the possible stress path dependence on or independence from the material under generalised stress including suction. In unsaturated non-expansive soils it is often found that the behaviour is stress-path independent if the trajectories include only loading and wetting (suction reduction) stages (Alonso et al., 1987). However, Gens \& Alonso (1992) argued that, in expansive soils, there would be irreversible macrostructural rearrangements caused by the swelling of the microstructure when wetting the samples. This interaction would be higher when applied stresses were low. As a consequence, this macrostructural change could result in stress-path dependence of volume changes even in the cases where only wetting paths are involved. This issue has been examined in this experimental programme.

Figure 14(a) shows void ratio variation for two specimens that share the initial and final stress points but have followed different stress paths. Note that the final state is different, so there is a measure of stress path dependence. As observed in other cases (Brackley, 1973; Justo et al., 1984), the final void ratio of the sample wetted under low stresses is higher. The disruption of the macrostructure would be more severe in this case because of the larger swelling strains developed during wetting, inducing large macrostructural volume changes that cannot be recovered upon subsequent loading.

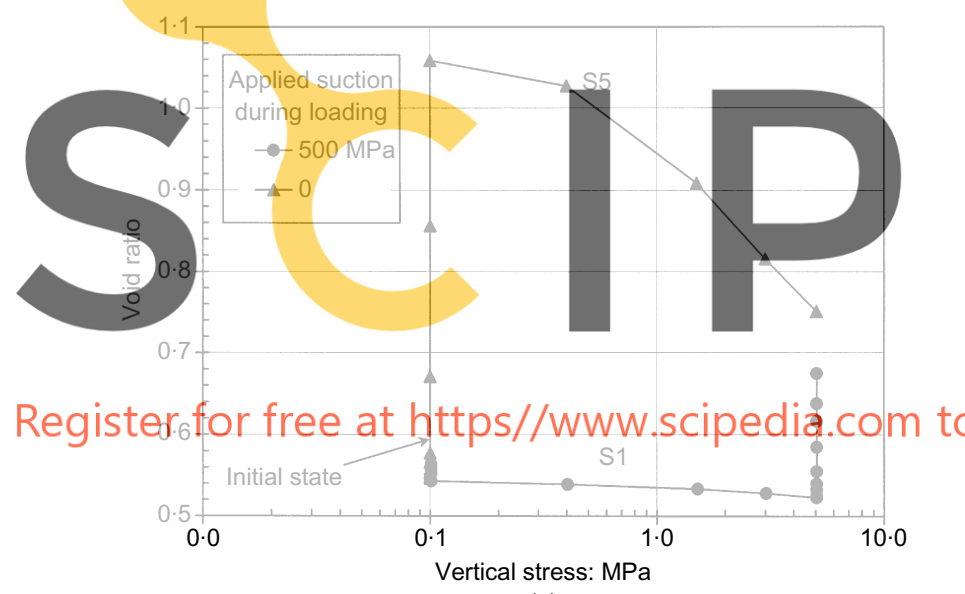

(a)

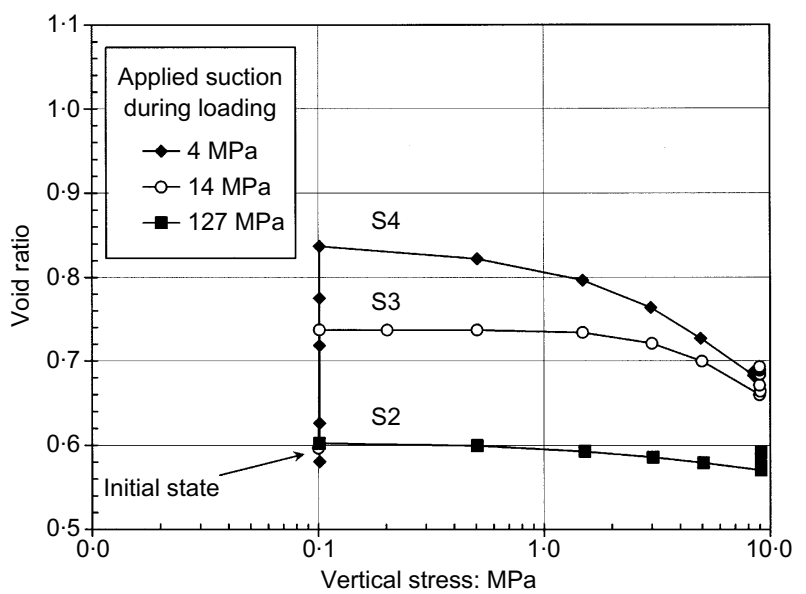

(b)

Fig. 14. Observed variation of void ratio with the same initial and final stress states: (a) tests S1 and S5; (b) tests S2, S3 and S4
Fig. 14(b) shows a similar plot for three other specimens with the same initial and final points where, again, the final void ratio values do not coincide. As before, the sample that was wetted at the lower applied vertical stress (4 MPa) reaches the highest final void ratio.

The main features of the swelling pressure tests performed in the UPC laboratory are presented in Table 2. Initially a suction change is applied to three of the samples in order to achieve a range of initial conditions for the next testing stage. During the swelling pressure phase a condition of no volume change is prescribed, and suction is reduced in stages under controlled conditions. In this way it is possible to follow the stress path, in terms of suction against vertical stress, throughout the tests, as shown in Fig. 15.

Examination of these stress paths provides important information on the stress-strain characteristics of the bentonite in this type of test (which corresponds to a number of relevant field situations) but, also, on the underlying causes of the observed behaviour. Three zones can be distinguished (Fig. 15). The first corresponds to the stage of high suction and low applied loads. In this region the vertical stress remains below the preconsolidation stress (in elasto-plastic terms, the stress state has not reached the yield locus) and the stress path is defined by the increase of load required to compensate for the small swelling strains due to suction reduction.

Once the preconsolidation pressure (yield locus) is reached, the second zone is entered and a drastic change of slope ensues. If the load is sufficiently high, collapse of the macrostructure occurs, and the value of vertical stress tends to reduce to compensate for the collapse compressive strains.

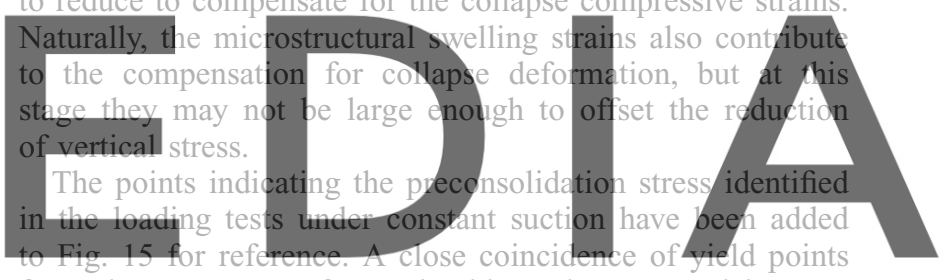

from the two types of test should not be expected because

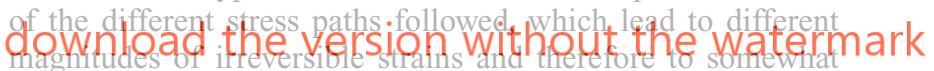
different yield surfaces. Generally, in the constant load tests the larger swelling strains should lead to smaller sizes of yield locus.

Finally, zone III corresponds to the region of low suction, where microstructural swelling strains exhibit their largest magnitude. Now microstructural strains overcome any possible collapse strains, and the vertical stress must increase again to compensate for the large swelling strains. It is interesting to note that even the rather complex behaviour displayed by the compacted bentonite during the swelling pressure tests can be readily explained in the context of a conceptual framework that considers the interaction between microstructure and macrostructure.

The dependence of swelling pressure on compacted dry density has been examined by a large number of tests performed in conventional oedometers without suction control, where the wetting is applied in a single step. The results of the swelling pressure tests performed in suctioncontrolled equipment have been added to Fig. 16, where it can be observed that they agree closely with the independently determined trend. It is reassuring that no spurious effects due to the equipment appear to affect the results of the swelling pressure tests.

\section{MODEL RESULTS}

In the previous section the test results have been qualitatively interpreted in terms of a conceptual framework in 
Table 2. Main features of the swelling pressure tests performed at the UPC laboratory

\begin{tabular}{|c|c|c|c|c|c|c|c|}
\hline \multirow[t]{3}{*}{ Test } & \multicolumn{2}{|c|}{ Initial conditions } & \multicolumn{4}{|c|}{ Path before swelling pressure test } & \multirow{3}{*}{$\begin{array}{l}\text { Dry density before } \\
\text { swelling pressure } \\
\text { test, } \rho_{\mathrm{d}}: \mathrm{Mg} / \mathrm{m}^{3}\end{array}$} \\
\hline & \multirow{2}{*}{$\begin{array}{c}\rho_{\mathrm{d}}: \\
\mathrm{Mg} / \mathrm{m}^{3}\end{array}$} & \multirow[t]{2}{*}{$w: \%$} & \multicolumn{2}{|c|}{ I } & \multicolumn{2}{|c|}{ II } & \\
\hline & & & $\sigma_{\mathrm{v}}: \mathrm{MPa}$ & $s: \mathrm{MPa}$ & $\sigma_{\mathrm{v}}: \mathrm{MPa}$ & $s: \mathrm{MPa}$ & \\
\hline$\overline{\mathrm{SP} 1}$ & $1 \cdot 62$ & $14 \cdot 6$ & $0 \cdot 11$ & 128 & $0 \cdot 11$ & 424 & $1 \cdot 65$ \\
\hline SP2 & 1.63 & $13 \cdot 2$ & $0 \cdot 15$ & 146 & & & 1.63 \\
\hline SP3 & 1.62 & 14.6 & $0 \cdot 16$ & 128 & $0 \cdot 16$ & 70 & 1.57 \\
\hline SP4 & 1.63 & $14 \cdot 2$ & $0 \cdot 15$ & 128 & $0 \cdot 15$ & 39 & 1.50 \\
\hline
\end{tabular}

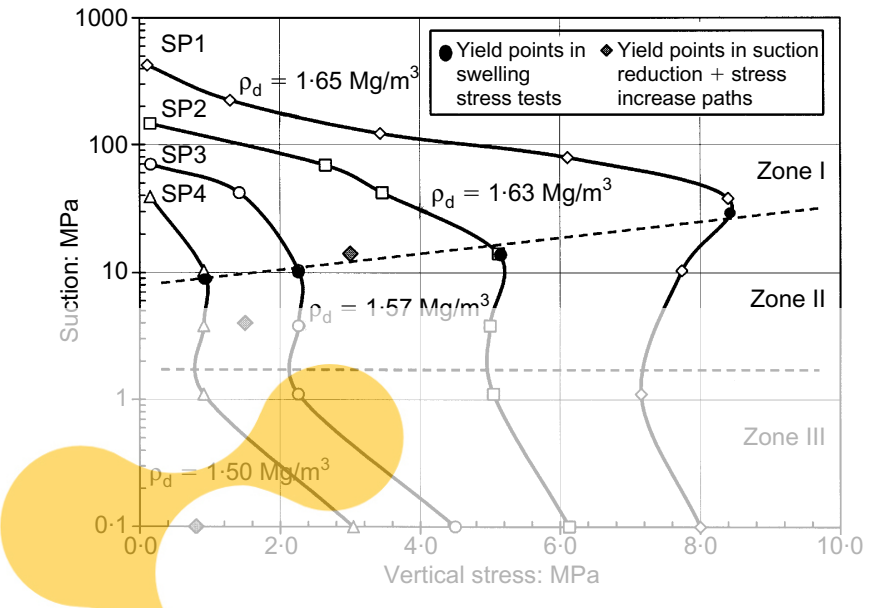

Fig. 15. Generalised stress paths observed in the swelling

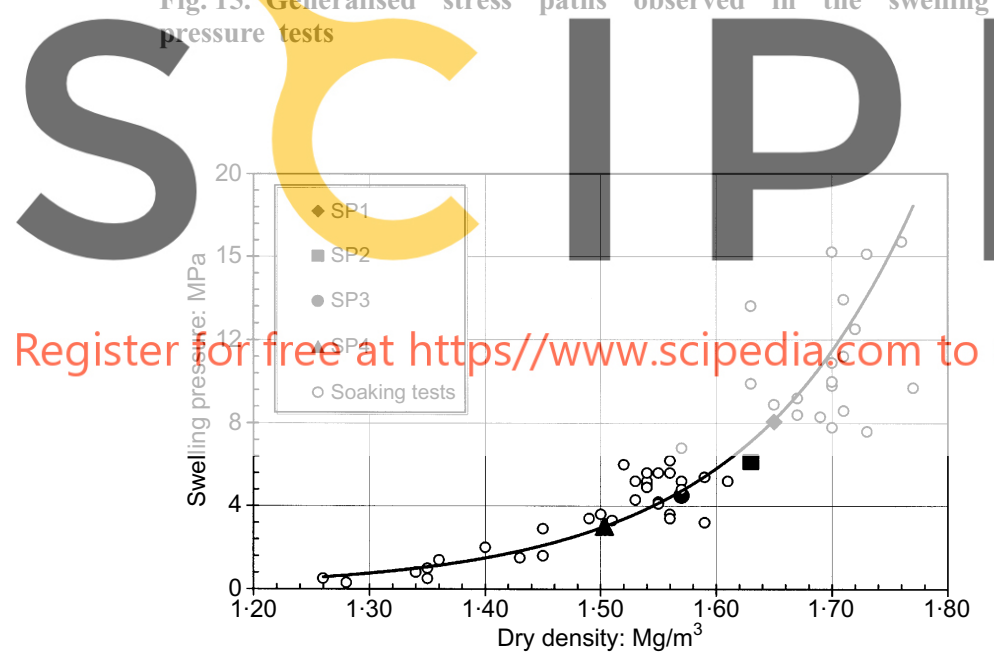

Fig. 16. Dependence of swelling pressure on compaction dry density as determined in conventional oedometers. The swelling pressures measured in the suction-controlled oedometers agree well with the general trend

which two structural levels (macro and micro) interact. Although this interaction has a dominant effect when examining the behaviour of compacted expansive clay, it may also be relevant to some aspects of the behaviour of non-expansive clays (see for instance the results of tests on kaolin reported by Sivakumar \& Doran, 2000).

Some references have also been made to general concepts of elasto-plasticity. However, a more satisfactory interpretation requires the use of a properly formulated constitutive law so that quantitative comparisons are possible and, more importantly, to ensure that the conceptual model used is internally consistent and has no arbitrary ad hoc rules. In this section some of the most characteristic results presented earlier are examined using the double-structure elasto-plastic model described in Sánchez et al. (2001). This model is based on the conceptual approach contained in Gens \& Alonso (1992) and on the mathematical formulation presented in Alonso et al. (1999). It is graphically summarised in Fig. 17. The behaviour of the macrostructure is defined in terms of the Barcelona Basic Model (BBM; Alonso et al., 1990), represented in the figure by the LC yield curve. The behaviour of the microstructure is considered always reversible and logarithmically dependent on the classical effective stress $p+s$, where $p$ is the mean net stress and $s$ is the suction (total suction in this case). When the stress state crosses either the SI (suction increase) or SD (suction decrease) yield locus, the microstructural strains induce irreversible plastic strains in the macrostructure that result in the movement of the LC yield surface. Important components of the model are the interaction functions that control the magnitude of the macrostructural plastic strain caused by

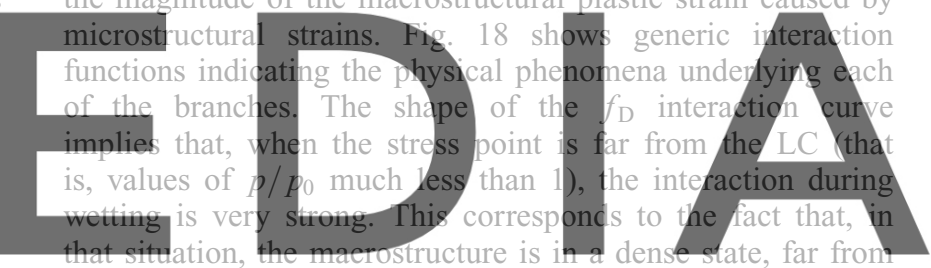

the collapsible behaviour implied by the LC curve. Therefore the qxpangion of the microstructure causes large disruptions moves towards the $\mathrm{LC}$, the specimen becomes less dense (relative to the applied stress), and the strength of the inter-

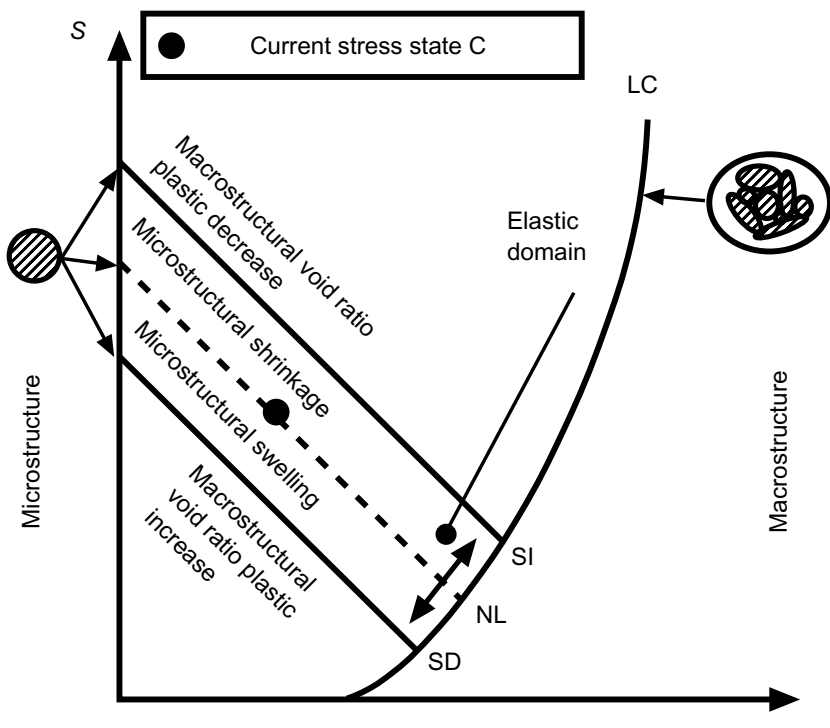

$p$

Fig. 17. Graphical summary of the double-structure elastoplastic model for expansive soils 


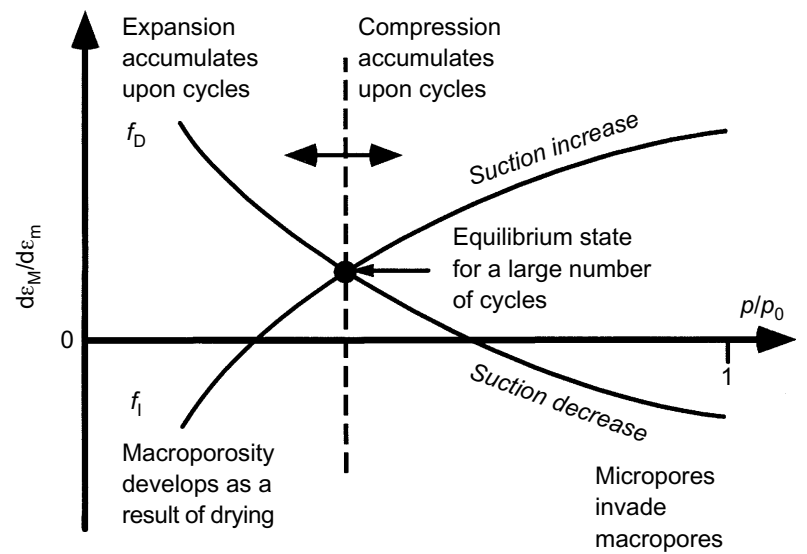

Fig. 18. Generic interaction functions that indicate the intensity of the interaction between the two structural levels

action reduces accordingly. Indeed, the interaction may change sign if the expansion of the aggregates leads to an invasion of the macropores with a consequent reduction of the macrostructural void ratio. Opposite considerations apply to the $f_{\mathrm{I}}$ interaction curve. Additional information on the model is given elsewhere (e.g. Gens \& Alonso, 1992; Alonso et al., 1999; Sánchez et al., 2001). The relevant model equations are presented in Appendix 1.

An important advantage of this model is that it makes it possible to take into account the two levels of structure really existing in the material tested, so that the variables associated with each level can be followed throughou the test and a more detailed examin behaviour can be made. It must of this modelling exercise is capability of the model. In fact, specifically to giye a specifically to give a

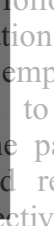
on of the pattens of
mphasised that the aim
to test the predictive
paranteters have been
representation of the
tive is to use the constitutive model as a consistent tool to gain a better underRegister for fre behavipur of the soil and of the mechanisms to

The model is used one-dimensionally, substituting applied vertical stress for mean net stress. Therefore $p$ now denotes net vertical stress. SI and SD surfaces coincide, so that there is always some degree of interaction between micro and macro levels. The parameters used in the modelling are shown in Table 3. The results of tests $\mathrm{S} 1$ and S5 have been used to determine them. Elastic macrostructural parameters have been obtained from the sections of the tests that are inside the LC yield curve. The value of the slope of the saturated consolidation line, $\lambda(0)$, has been based on the loading stage of test S5. The parameters of the interaction curves have been adjusted to yield the correct amount of stress path dependence, and the parameters for the microstructural behaviour have been derived from the swelling stages of tests S1 and S5. Finally, the parameters controlling the shape of the LC yield surface have been evaluated from the experimental results plotted in Fig. 10, which shows the variation of the apparent preconsolidation stress with suction.

The initial values of the microstructural and macrostructural void ratio are $0 \cdot 45$ and $0 \cdot 11$ respectively, in accordance with the observations on the soil fabric. The static compaction stress $(18 \mathrm{MPa})$ gives the initial position of the LC yield surface. With the expression used to define the LC curve (equation (1)), the hardening parameter $p_{0}^{*}$ has an initial value of $12 \mathrm{MPa}$.

The model is first applied to the analysis of tests S1 and S5. They share the same initial and final generalised stress states but their trajectories are very different (Fig. 19(a)). In test $\mathrm{S} 1$ the specimen is loaded under a high $(550 \mathrm{MPa})$ suction up to a $5.1 \mathrm{MPa}$ vertical load and is then wetted, reducing the suction to zero in stages. In contrast, test S5 is first wetted at a low applied vertical stress value of $0 \cdot 1 \mathrm{MPa}$ and then the sample, already saturated, is loaded to a vertical stress of 5.0 MPa. These two tests therefore provide the opportunity to examine the behaviour over a wide range of stress paths. Fig. 19(a) shows the computed variation of void ratio over the stress paths followed by the two tests, together with the experimental results. Major features of behaviour are correctly reproduced, including the following:

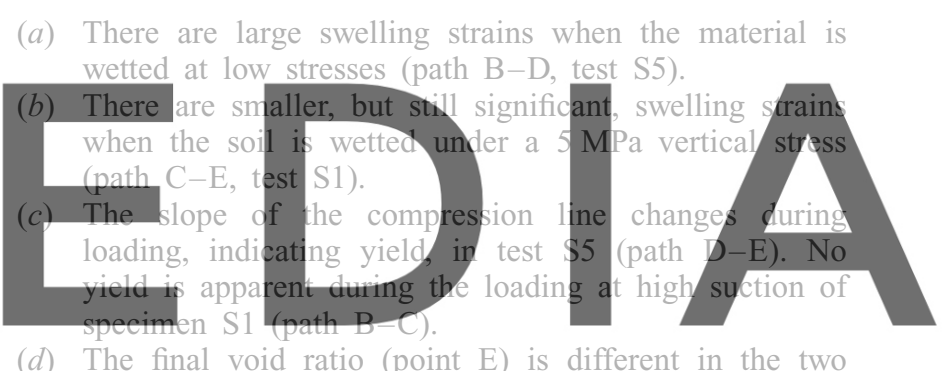

(d) The final void ratio (point E) is different in the two

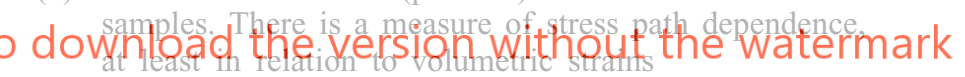

Good reproduction of behaviour is also achieved when considering the experimental results in terms of void ratio against suction variation (Fig. 19(b)), although some departures are observed at intermediate stages of the swelling of test S5.

To summarise, the model is capable of offering a good simulation of the observed results, and, with the set of parameters adopted, even the quantitative agreement is quite close. Accepting then that the constitutive law is a reasonable representation of the real behaviour, it is interesting to explore the further information that can be obtained from

Table 3. Parameters used to define the elasto-plastic constitutive law used in modelling

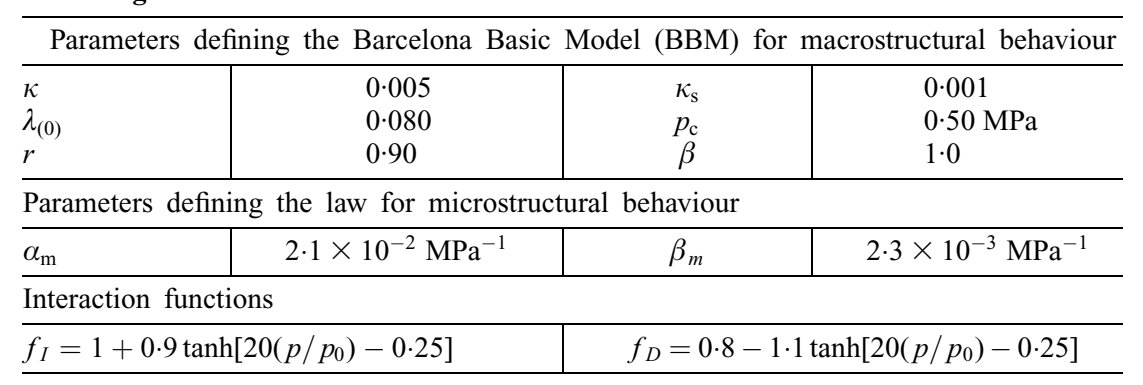



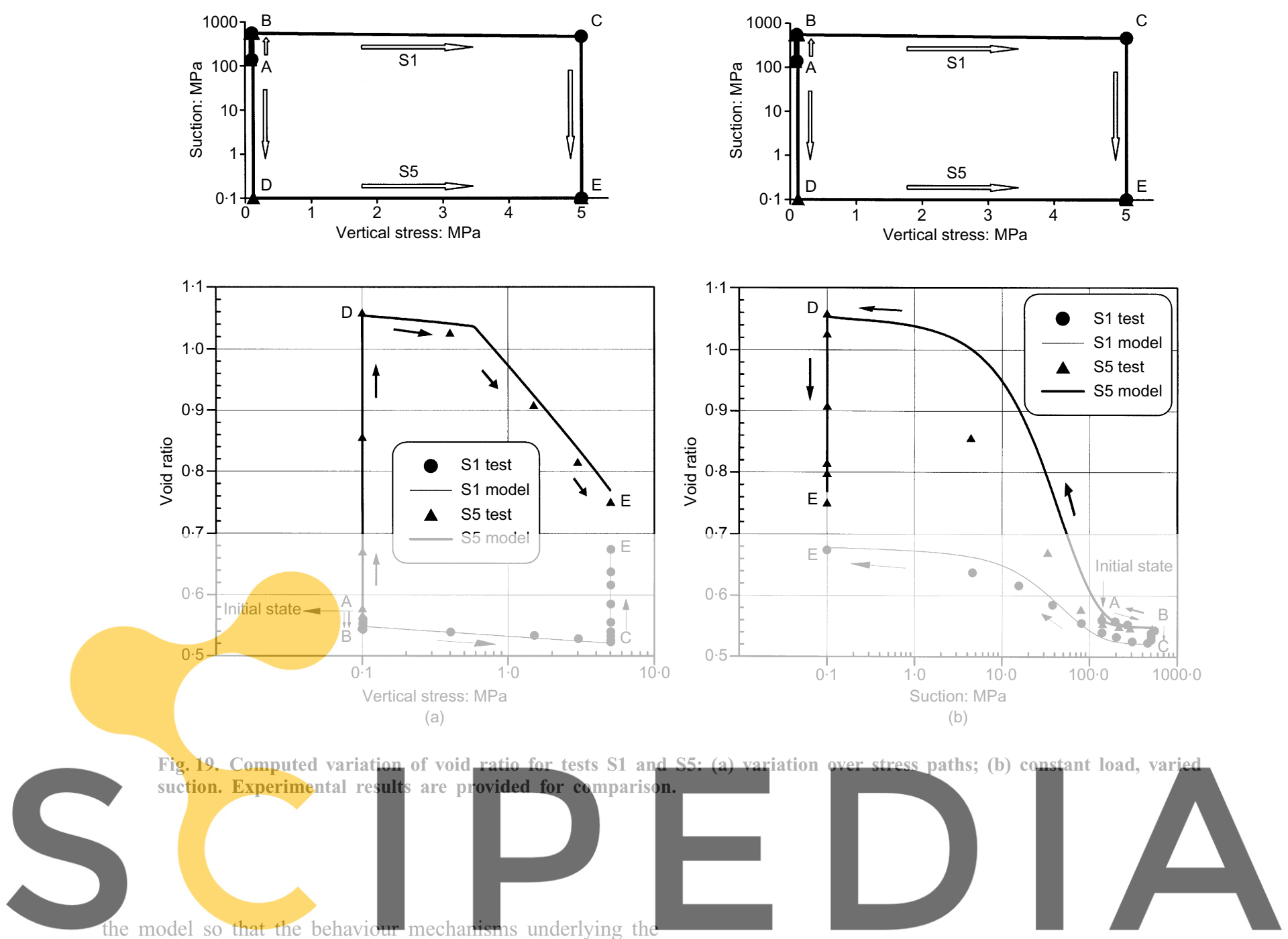

mechanical behaviour of the soil can be better understood.

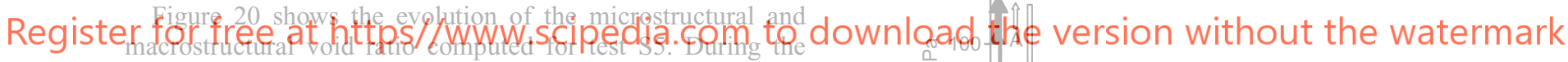
swelling stage (path B-D), the microstructural strains are relatively large, and they cause even larger irreversible strains in the macrostructure because of the large coupling between the two structural levels that exist at low stresses. During the subsequent loading (path D-E) under saturated conditions the deformation of the macrostructure is significant, but it is not due to microstructural strains, which are now quite small. This part of the test is basically controlled by the behaviour of the macrostructure. Fig. 21 shows the parts of the interaction functions involved in the various stages of the test.

Some of the positions of the LC yield curve during the performance of test S5 are shown in Fig. 22. It can be seen that during swelling (path B-D) the LC curve moves to the left in response to the irreversible swelling strains taking place in the macrostructure. Subsequent loading (path D-E) takes the LC again to the right to the final load value of 5.0 MPa. Indeed the yield point observed and computed (Fig. 19(a)) corresponds to the crossing of the LC during this loading stage. Continuous information on the evolution of the LC yield curve can be obtained by plotting the evolution of the hardening parameter, $p_{0}^{*}$ (Fig, 23). The reduction of $p_{0}^{*}$ during swelling and subsequent increase upon loading are readily apparent.

The behaviour of sample S1 is quite different (Figs 24 and 25). During the first stage of drying (path $\mathrm{A}-\mathrm{B}$ ) and subsequent loading (path B-C), the microstructural volumetric strains are very small. The macrostructural strains are
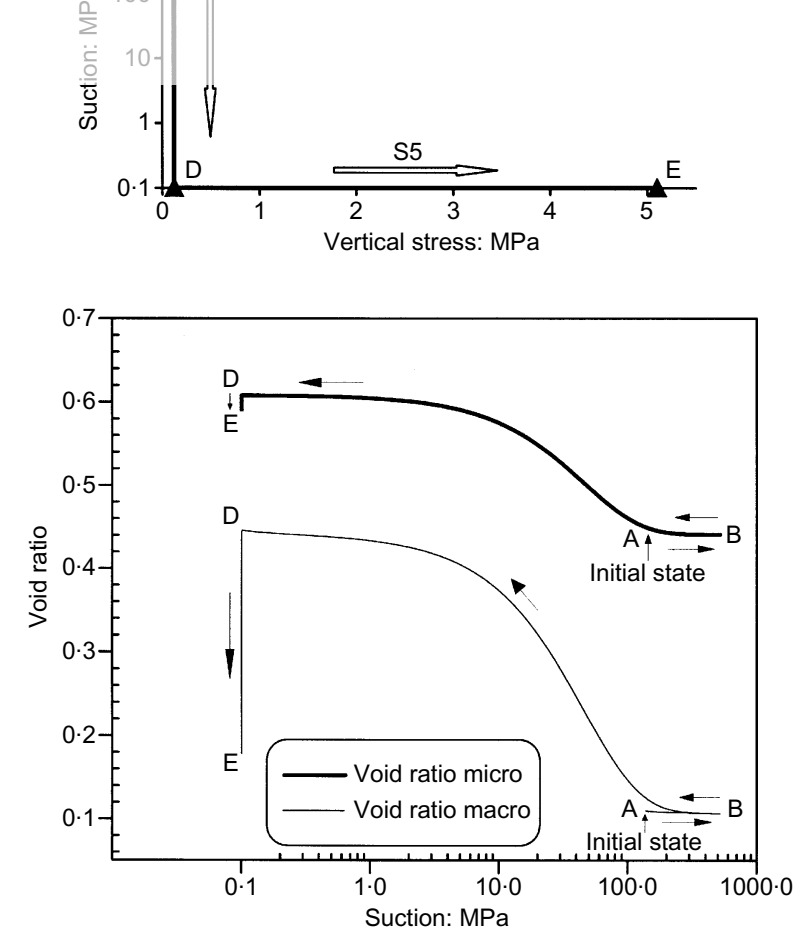

Fig. 20. Evolution of computed microstructural and macrostructural void ratio. Test $\mathrm{S5}$ 

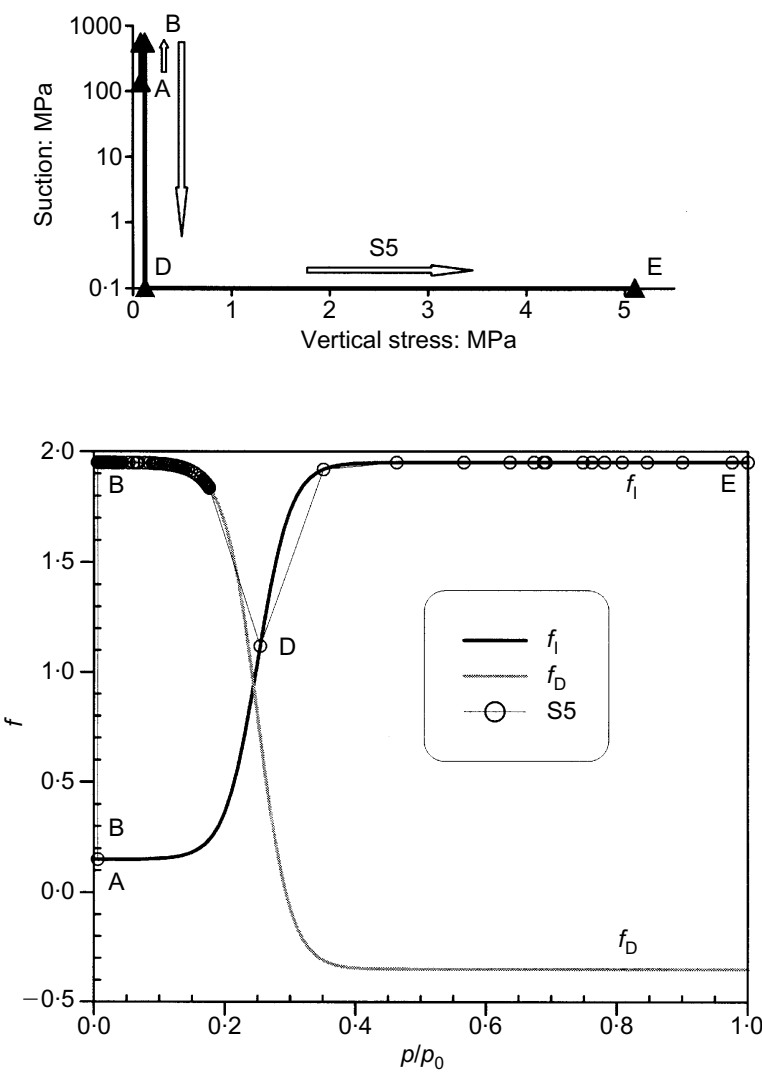

Fig. 21. Interaction functions involved in the various stages of tests S5
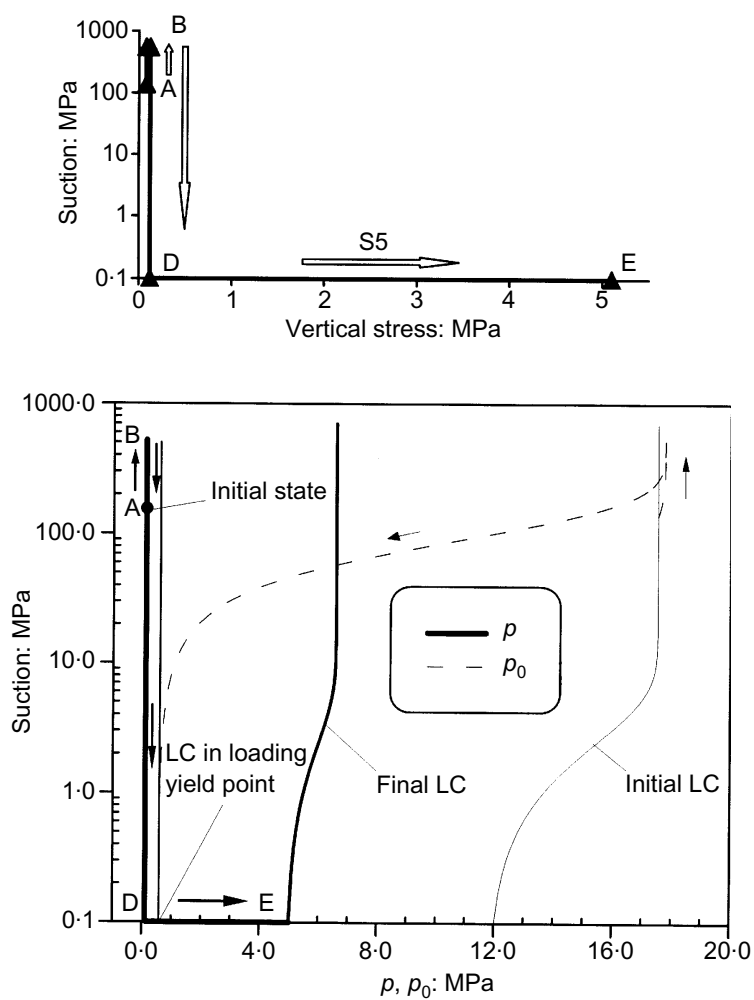

Fig. 22. Stress path and successive LC yield surfaces for test S5

also small even during loading because of the high stiffness imparted to the sample by the large $(500 \mathrm{MPa})$ suction. During the swelling stage (path $\mathrm{C}-\mathrm{E}$ ) under a $5 \cdot 1 \mathrm{MPa}$ load, the microstructural strains are significant although smaller
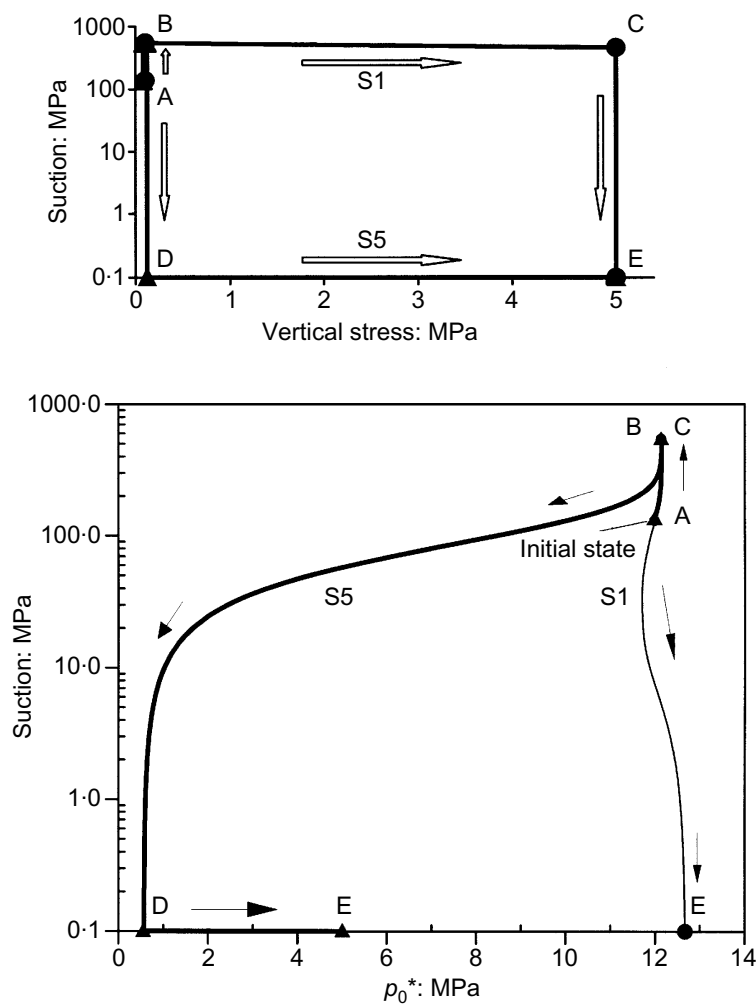

Fig, 23. Evolution of hardening parameter $p_{0}^{*}$ for tests S1 and S5
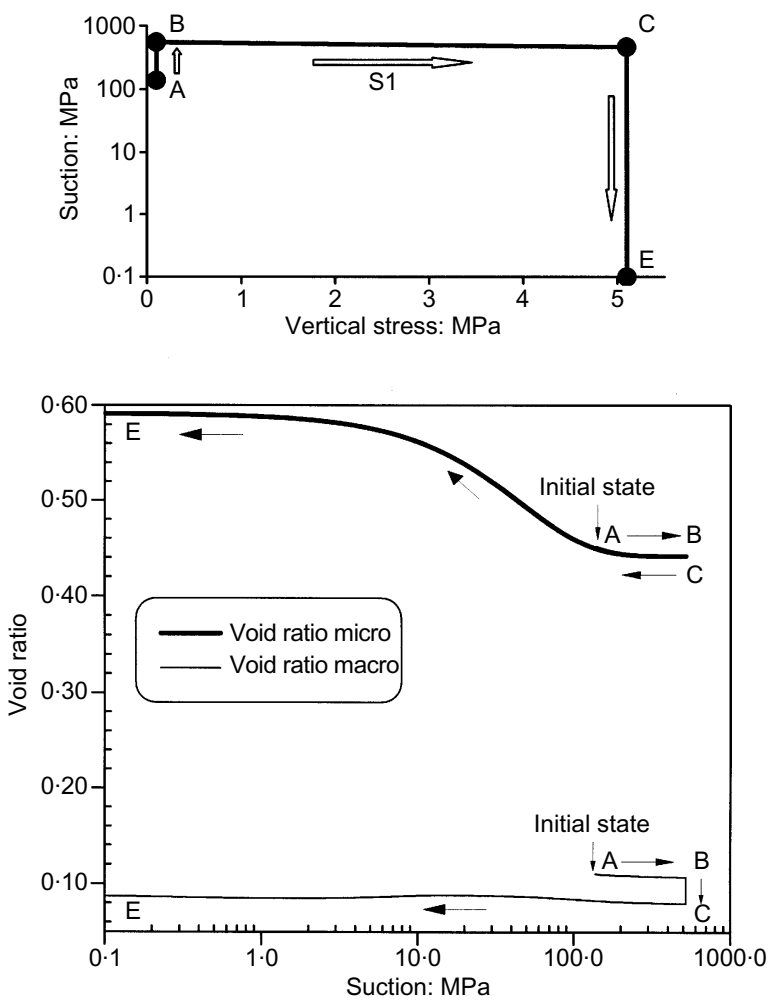

Fig. 24. Evolution of computed microstructural and microstructural void ratio. Test $\mathrm{S} 1$

than for test S5 because of the higher load applied. The most significant difference is, however, that the macrostructural strains that are induced are quite small because now the stress state is much closer to the LC (Fig. 26): that is, 

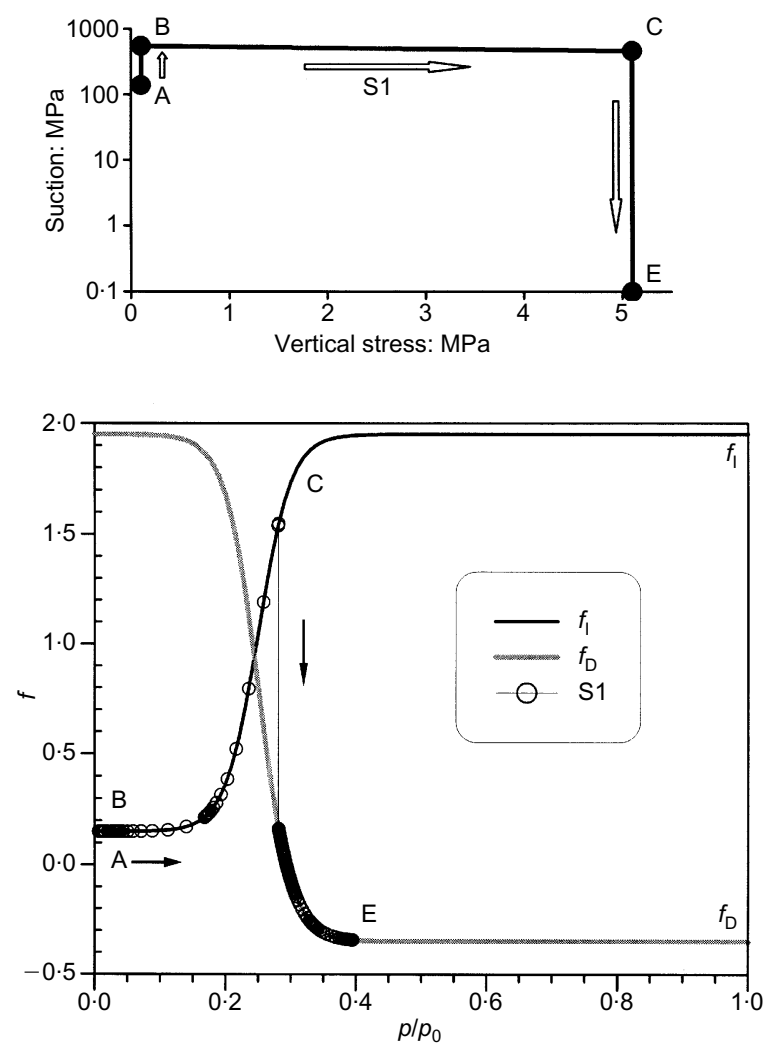

Fig. 25. Interaction involved in the various stages of tests S1
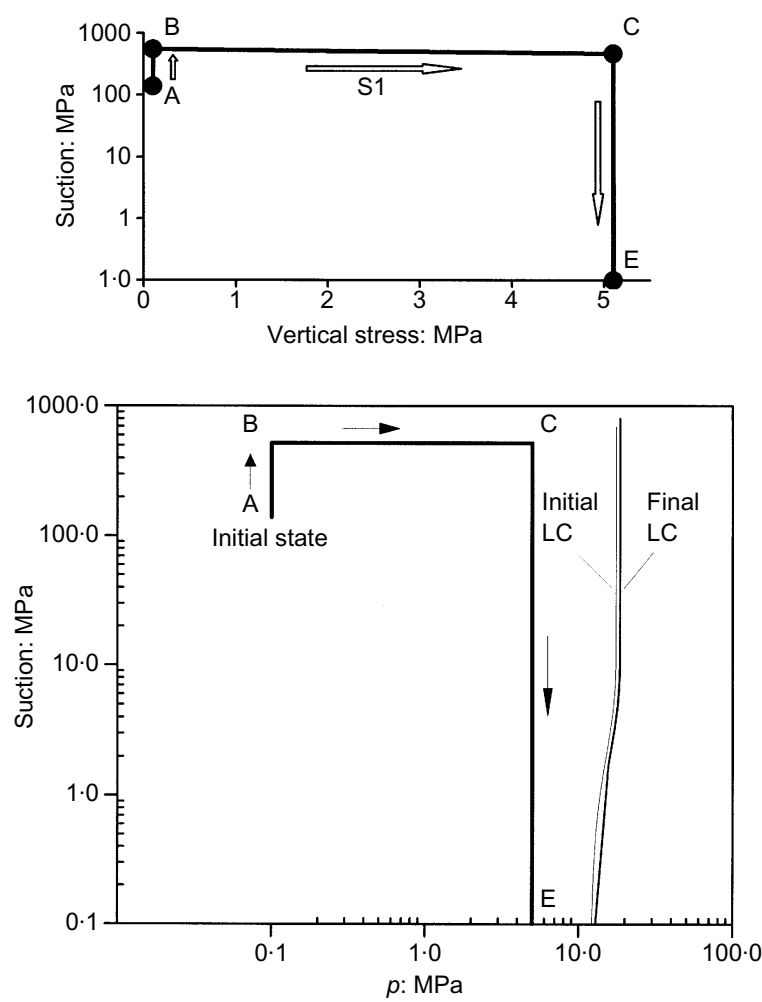

Fig. 26. Stress path and LC yield surfaces for test S5

the sample is in a comparatively loose state and the potential for macrostructural disruption is much lower. The loading stage (path B-C) takes place inside the LC yield surface, so no yield is expected and none was observed. The evolution of the hardening parameter for test S1 has also been plotted in Fig. 23. It can be observed that the changes are very slight (indicating a LC curve that is practically stationary) and that the final value of $p_{0}^{*}$ is higher than for test S5.

Now the basic reason for the stress path dependence of volumetric strains can be readily identified. The basic difference is that, in test S5, the large swelling strains take place at low stress values, and consequently the interaction with the macrostructure is very strong and results in large plastic strains that are not fully recovered upon subsequent loading. In test S1, development of plastic strains in the macrostructure is quite reduced because, when the swelling of the microstructure takes place, the interaction between the two structural levels is small. The different states of the samples at the end of the test are reflected in the different final positions of the LC curves (and $p_{0}^{*}$ values). Exactly the same analysis could be made regarding the results of tests $\mathrm{S} 2, \mathrm{~S} 3$ and S4.

As a final test of the adequacy of the model to represent the behaviour of compacted swelling materials, it has been applied to the modelling of the swelling pressure tests using the same set of parameters without any attempt at further calibration. Fig. 27 shows the results of the model calculations together with the experimental results. Although differences between computed and experimental results can be observed, the model is capable of producing swelling stress paths very similar to the observed ones comprising the three phases of behaviour identified previously.

\section{CONCLUSIONS}

The mechanical behaviour of compacted bentonite has been investigated by the performance of a testing programme carried out in suction-controlled oedometers capable of applying high suctions and large vertical loads. Two types of test have been performed: (a) tests with simultaneous control of vertical stress and suction, and (b) suction-controlled swelling pressure tests. Examination of the results has revealed significant features of behaviour, such as yield phenomena, dependence of swelling strains on applied stresses, stress path dependence of strains, and compound stress paths in swelling pressure tests. In spite of the complexity of the behaviour, a good understanding of the behaviour is possible by considering explicitly the fabric of the soil, which has been independently studied, revealing a dual arrangement with microstructural and macrostructural components.

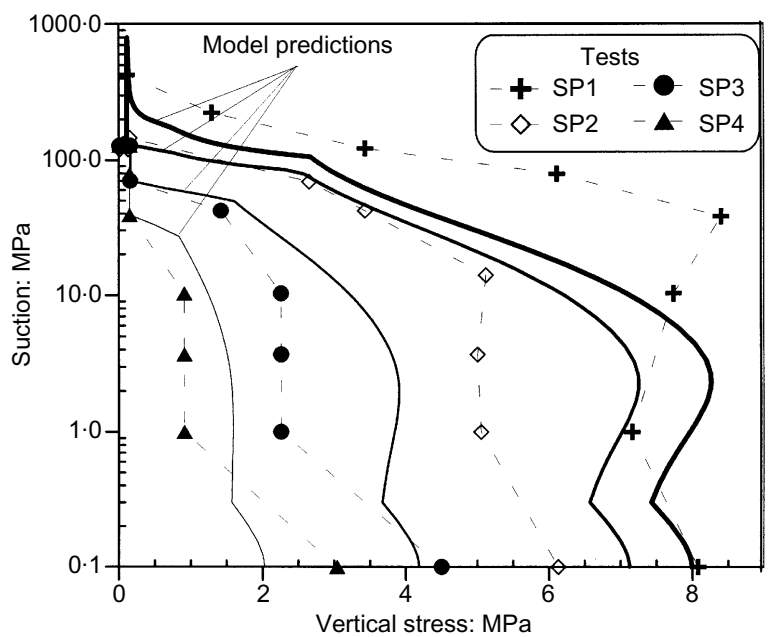

Fig. 27. Computed stress paths for swelling pressure tests SP1SP4. Experimental results provided for comparison 
A deeper insight into the behaviour of the compacted bentonite, and of the basic mechanisms controlling it, has been achieved using an elasto-plastic framework that incorporates the interplay between microstructural and macrostructural fabric levels in a simplified manner. Most of the main features of behaviour are correctly reproduced by the model, allowing a more detailed examination of the role that the different variables play on the explanation of the overall behaviour of the soil.

\section{ACKNOWLEDGEMENTS}

This work has been supported by ENRESA and the European Commission through contract FI4W-CT95-006 (FEBEX I). The authors also wish to acknowledge the support of the Ministerio de Ciencia y Tecnología through research grant BTE2001-2227.

\section{APPENDIX 1}

The relevant equations for the elasto-plastic model are as follows.

\section{LC yield surface:}

$p_{0}=p_{c}\left(\frac{p_{0}^{*}}{p_{c}}\right)^{\frac{\lambda(0)-\kappa}{\lambda(s)-\kappa}}$ and $\lambda(s)=\lambda(0)\left[r+(1-r) \mathrm{e}^{-\beta \mathrm{s}}\right]$

Hardening law:

$\frac{\mathrm{d} p_{0}^{*}}{p_{0}^{*}}=\frac{\left(1+e_{\mathrm{M}}\right) \mathrm{d} \varepsilon_{\mathrm{v}}}{\lambda(0)-\kappa}$

Elastic macrostructural behaviour (reversible):

$$
\begin{aligned}
\mathrm{d} \varepsilon_{\mathrm{vM}}^{\mathrm{e}} & =\frac{\mathrm{d} p}{K_{t}}+\frac{\mathrm{d} s}{K_{\mathrm{s}}} \text { with } K_{t}=\frac{\left(1+e_{\mathrm{M}}\right) p}{\kappa} \text { and } \\
K_{\mathrm{S}} & =\frac{\left(1+e_{\mathrm{M}}\right)\left(s+p_{\mathrm{atm}}\right)}{\kappa_{\mathrm{s}}}
\end{aligned}
$$

Microstructural behaviour (reversible)

$\mathrm{d} \varepsilon_{\mathrm{vm}}^{\mathrm{e}}=\frac{\mathrm{d}(p+s)}{\mathrm{K}_{\mathrm{m}}}$ with $K_{\mathrm{m}}=\frac{\mathrm{e}^{-\alpha_{\mathrm{m}}(p+s)}}{\beta_{\mathrm{m}}}$

Interaction micro-macro:

$\mathrm{d} \varepsilon_{\mathrm{vM}}^{\mathrm{p}}=f_{\mathrm{D}} \mathrm{d} \varepsilon_{\mathrm{vm}}^{\mathrm{e}}$ when SD is activated

$\mathrm{d} \varepsilon_{\mathrm{vM}}^{\mathrm{p}}=f_{\mathrm{I}} \mathrm{d} \varepsilon_{\mathrm{vm}}^{\mathrm{e}}$ when SI is activated

\section{NOTATION}

$e$ void ratio

$e_{\mathrm{M}}$ macrostructural level void ratio

$f_{\mathrm{I}}, f_{\mathrm{D}}$ interaction function between micro and macrostructural levels for suction increase and decrease respectively

$K_{\mathrm{m}} \quad$ microstructural bulk modulus for changes in suction plus mean stress

$K_{\mathrm{s}} \quad$ macrostructural bulk modulus for changes in suction

$K_{\mathrm{t}}$ macrostructural bulk modulus for changes in mean stress

$p$ net mean stress (excess of mean stress over gas pressure)

$p_{\mathrm{c}}$ reference stress

$p_{0}$ net mean yield stress at current suction

$p_{0}^{\prime} \quad$ net mean yield stress for saturated conditions

$p_{\text {atm }}$ atmospheric pressure $(0 \cdot 1 \mathrm{MPa})$

$r$ parameter defining the maximum macrostructural soil stiffness

$s$ suction

$w$ gravimetric water content $\alpha_{\mathrm{m}}$ parameter controlling the rate of increase of microstructural soil stiffness with mean stress

$\beta$ parameter controlling the rate of increase of macrostructural soil stiffness with suction

$\beta_{\mathrm{m}}$ parameter controlling the microstructural soil stiffness

$\varepsilon_{\mathrm{V}}$ total volumetric strains

$\varepsilon_{\mathrm{vM}}^{\mathrm{e}}, \varepsilon_{\mathrm{vM}}^{\mathrm{p}}$ elastic and plastic volumetric strains at macrostructural level

$\varepsilon_{\mathrm{vm}}^{\mathrm{e}} \quad$ elastic volumetric strain at microstructural level

$\kappa$ macrostructural elastic stiffness parameter for changes in net mean stress

$\kappa_{\mathrm{s}}$ macrostructural elastic stiffness parameter for changes in suction

$\lambda(s) \quad$ macrostructural stiffness parameter for changes in net mean stress for virgin states of soil at suction $s$

$\rho_{\mathrm{d}}$ dry density

$\sigma_{\mathrm{v}}$ net vertical stress (excess of vertical stress over gas pressure)

\section{REFERENCES}

Al-Mukhtar, M., Qi, Y., Alcover, J. F. \& Bergaya, F. (1999). Oedometric and water-retention behavior of highly compacted unsaturated smectites. Can. Geotech. J. 36, 675-684.

Alonso, E. E. (1998). Modelling expansive soil behaviour: keynote lecture. Proc. 2nd. Int. Conf. Unsaturated Soils, Beijing 2, $37-70$.

Alonso, E. E., Gens, A. \& Hight, D. W. (1987). Special problem soils: general report. Proc. 9th Eur. Conf. Soil Mech. Found. Engng 3, 1987-1146.

Alonso, E. E., Gens, A. \& Josa, A. (1990). A constitutive model for partially saturated soils. Géotechnique 40, No. 3, 405-430.

Alonso, E. E., Vaunat, J. \& Gens, A. (1999). Modelling the mechanical behaviour of expansive clays. Engng Geol. 54, 173-183.

Atabek, R. B. , Felix, B., Robinet, J. C. \& Lahlou, R. (1991). Rheological behaviour of saturated expansive clay materials. Workshop on Stress Partitioning in Engineered Clay Barriers, Duke University, Durham, NC.

Bernier, F., Volckaert, G., Alonso, E. \& Villar, M. (1997). Suctioncontrolled experiments on Boom clay. Engng Geol. 47, 325338 .

Bjerrum, L., Brekke, T. L., Moum, J. \& Selmer-Olsen, R. (1964). Some Norwegian studies and experiences with swelling materials in rock gauges. NGI Publication, Oslo, No. 57.

Brackley, I. J. (1973). Swell pressure and free swell in compacted clay. Proc. 3rd Int. Conf. Expansive Soils, Haifa 1, 169-176.

Callaghan, I. C. \& Ottewill, R. H. (1974). Interparticle forces in montmorillonite gels. Faraday Discuss. Chem. Soc. 57, $110-118$.

Cui, Y. J., Loiseau, C. \& Delage, P. (2002a). Microstructure changes of a confined swelling soil due to suction controlled hydration. Proc. 3rd Int. Conf. Unsaturated Soils, Recife 2, 593-598.

Cui, Y. J., Yahia-Aissa, M. \& Dalage, P. (2002b). A model for the volume change behavior of heavily compacted selling clays. Engng Geol. 64, 233-250.

Cuisinier, O. \& Masrouri, F. (2001). Study of the hydromechanical behaviour of a swelling soil from low to very high suctions. Proc. 6th Int. Workshop Key Issues in Waste Isolation Research, Paris, 61-70.

Delage, P., Howat, M. D. \& Cui, Y. J. (1998). The relationship between suction and swelling properties in a heavily compacted unsaturated clay. Engng Geol. 50, 117-126.

Dueck, A. \& Börgesson, L. (2001). Constant volume tests with suction control performed on a swelling clay. Proc. 6th Int. Workshop Key Issues in Waste Isolation Research, Paris, 83-101.

Escario, V. \& Sáez, J. (1973). Measurement of the properties of swelling and collapsing soils under controlled suction. Proc. 3rd Int. Conf. Expansive Soils, Haifa, 2, 195-200.

Esteban, F. (1990). Caracterización experimental de la expansividad de una roca evaporítica. $\mathrm{PhD}$ thesis, Universidad de Canabria, Santander (in Spanish).

Gens, A. \& Alonso, E. E. (1992). A framework for the behaviour of unsaturated expansive clays. Can. Geotech. J. 29, 1013-1032. 
Justo, J. L., Delgado, A. \& Ruiz, J. (1984). The influence of stresspath in the collapse-swelling of soils at the laboratory. Proc. 5th Int. Conf. Expansive Soils, Adelaide, 67-71.

Kraehenbuehl, F., Stoeckli, M. F., Brunner, F., Kahr, G. \& MüllerVonmoos, M. (1987). Study of the water-bentonite system by vapour adsorption, immersion calorimetry and X-ray technique: I. Micropore volumes and internal surface areas, following Dubinin's theory. Clay Miner. 22, 1-9.

Koch, D. (2002). Bentonites as a basic material for technical base liners and site encapsulation cut-off walls. Appl. Clay Sci. 21, $1-11$.

Martin, R. T. (1962). Adsorbed water on clay: a review. Proc. 9th Nat. Conf. Clays and Clay Minerals, Purdue University Pergamon Press: Oxford, 28-70.

Ormerod, E. C. \& Newman, A. C. D. (1983). Water sorption of Casaturated clays: II. Internal and external surfaces of montmorillonite. Clay Miner. 18, 289-299.

Pusch, R. (1982). Mineral-water interactions and their influence on the physical behaviour of highly compacted $\mathrm{Na}$ bentonite. Can. Geotech. J. 19, 381-387.

Pusch, R. \& Moreno, L. (2001). Saturation and permeation of buffer clay. Proc. 6th Int. Workshop Key Issues in Waste Isolation Research, Paris, 71-81.

Romero, E., Gens, A. \& Lloret, A. (1999). Water permeability, water retention and microstructure of unsaturated Boom clay. Engng Geol. 54, 117-127.

Sánchez, M., Gens, A., Gimaraes, L. N. \& Olivella, S. (2001). Generalized plasticity model for THM simulations involving expansive clays. Proc. $6^{\text {th }}$ Int. Workshop Key Issues on Waste Isolation Research, Paris, 397-415.

Sivakumar, V. \& Doran, I. G. (2000). Yielding characteristics of unsaturated compacted soils. Mech. Cohesive-Frictional Mater. 5, 291-303.

Tang, G. X., Graham, J., Blatz, J., Gray, M. \& Rajapakse, R. K. N. D. (2002). Suctions, stresses and strengths in unsaturated sandbentonite. Engng Geol. 64, 147-156.

Villar, M. V. (1999). Investigation of the behaviour of bentonite by means of suction-controlled oedometer tests. Engng Geol. 54, $67-73$.

Villar, M. V. (2002). Thermo-hydro-mechanical characterisation of a bentonite from Cabo de Grata. $\mathrm{PhD}$ thesis, Universidad Complutense, ENRESA Technical Report 04/2002, Madrid.

Villar, M. V. \& Lloret, A. (2001). Variation of the intrinsic permeability of expansive clay upon saturation. Proceedings of the International Symposium on Suction, Swelling, Permeability and Structure of Clays, Shizuoka, 259-266.

Warkentin, B. P., Bolt, G. M. \& Miller, R. D. (1957). Swelling pressure of montmorillonite. Soil Sci. Soc. Am. Proc. 21, 495497.

Wiebe, B., Graham, J., Tang, G. X. \& Dixon, D. (1997). Influence of pressure, saturation, and temperature on the behaviour of unsaturated sand-bentonite. Can. Geotech. J. 35, 194-205.

Yong, R. N. (1999). Overview of modeling of clay microstructure and interactions for prediction of waste isolation barrier performance. Engng Geol. 54, 83-91. 